University of Louisville

ThinkIR: The University of Louisville's Institutional Repository

$12-2017$

\title{
Greater London in the 21st century : assessing coastal flooding mitigation preparedness and regional population risk in the face of projected sea-level rise.
}

\author{
Nathan K Wright \\ University of Louisville
}

Follow this and additional works at: https://ir.library.louisville.edu/etd

Part of the Environmental Indicators and Impact Assessment Commons

\section{Recommended Citation}

Wright, Nathan K, "Greater London in the 21st century : assessing coastal flooding mitigation preparedness and regional population risk in the face of projected sea-level rise." (2017). Electronic Theses and Dissertations. Paper 2841.

https://doi.org/10.18297/etd/2841

This Master's Thesis is brought to you for free and open access by ThinkIR: The University of Louisville's Institutional Repository. It has been accepted for inclusion in Electronic Theses and Dissertations by an authorized administrator of ThinkIR: The University of Louisville's Institutional Repository. This title appears here courtesy of the author, who has retained all other copyrights. For more information, please contact thinkir@louisville.edu. 


\title{
GREATER LONDON IN THE $21^{\text {ST }}$ CENTURY: ASSESSING COASTAL FLOODING MITIGATION PREPAREDNESS AND REGIONAL POPULATION RISK IN THE FACE OF PROJECTED SEA-LEVEL RISE
}

\author{
By \\ Nathan Wright \\ B.S.B.A, University of Louisville, 2010 \\ A Thesis submitted to \\ College of Arts \& Sciences \\ In Partial Fulfillment of the Requirements \\ for the Degree of \\ Master of Science \\ in Applied Geography \\ Department of Geography \& Geosciences \\ University of Louisville \\ Louisville, Kentucky
}

December 2017 
Copyright 2017 by Nathan Kyle Wright

All rights reserved 

GREATER LONDON IN THE $21^{\text {ST }}$ CENTURY: ASSESSING COASTAL FLOODING MITIGATION PREPAREDNESS AND REGIONAL POPULATION RISK IN THE FACE OF PROJECTED SEA-LEVEL RISE

\author{
By \\ Nathan Wright \\ B.S.B.A., University of Louisville, 2010 \\ A Thesis Approved on
}

November 30, 2017

By the following Thesis Committee:

Dr. Keith Mountain

Dr. Andrew Day

Dr. Matthew Ruther 


\section{DEDICATION}

I dedicate this work to all the late scientists who we are standing on the shoulders of, the current scientists who are carrying the baton, and to all the future scientists who will expand our work long after our time has passed. 


\section{ACKNOWLEDGMENTS}

I would like to thank the Department of Geography and Geosciences at the University of Louisville for financial support during the course of this work. I would also like to give personal thanks to the following: Dr. Jafar Hadizadeh for his valuable input and feedback during the writing of this work, guiding me through the research process, and piquing my interest in hazards based research, the late Dr. Carol Hanchette for helping usher me into this program, offering the graduate assistant opportunity, and facilitating smooth transitions during the academic advising processes, Dr. Andrew Day for his tutelage on the hydrological aspects of this study, Dr. Matthew Ruther for his assistance, suggestions, and patience regarding the population data, Dr. Keith Mountain for his continued oversight and suggestions to best approaching this research topic, and the rest of the faculty and staff for providing valuable insight regarding their own unique expertise while making this learning experience so hospitable. I would also like to thank Beau Kilpatrick for his feedback on diction, Daniel Tatum for his expertise with Excel formulas, Daniel Russell for his oversight on formatting and the rest of my friends and family for their love and support as well as my student peers for their collaborations, encouragement, and fellowship throughout this academic journey. I am sincerely grateful for all of the opportunities granted to me during my time here at the University of Louisville. 


\title{
ABSTRACT \\ GREATER LONDON IN THE $21^{\text {ST }}$ CENTURY: ASSESSING COASTAL FLOODING MITIGATION PREPAREDNESS AND REGIONAL POPULATION RISK IN THE FACE OF PROJECTED SEA-LEVEL RISE
}

\author{
Nathan K. Wright
}

November 30, 2017

Recent projections of $+6-9 \mathrm{~m}$ sea-level rise (SLR) over the next several decades present many social challenges for coastal regions during the $21^{\text {st }}$ century. These projections were applied to Greater London, UK as areal interpolated historical census data was overlaid on a 50m DEM alongside a polyline projection of the Thames Barrier. Population was projected to milestones of 2041, 2071, and 2101 using a capped, aggregated growth rate for each polygon while SLR was simulated through raster calculation for $1 \mathrm{~m}, 5 \mathrm{~m}$, and $9 \mathrm{~m}$ scenarios. The Thames Barrier maintained integrity for $1 \mathrm{~m}$ and $5 \mathrm{~m}$ scenarios but was breached at $9 \mathrm{~m}$. Population continued to increase in vulnerable areas as the floodplain expanded and results present a call to action for global authorities to both reduce social influences upon climate change and develop mitigative strategies to combat potential adverse effects during the $21^{\text {st }}$ century. 


\section{TABLE OF CONTENTS}

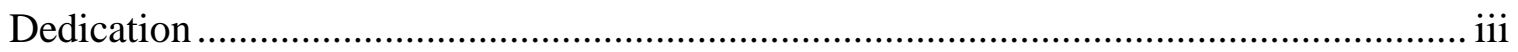

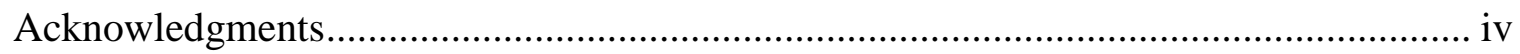

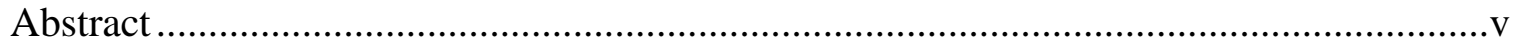

List of Figures ................................................................................................... vii

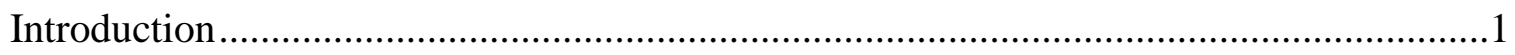

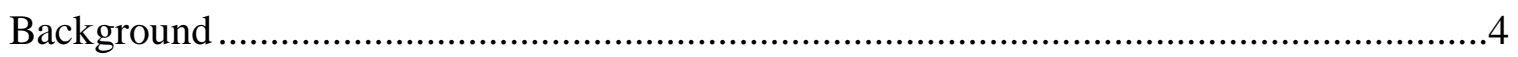

Study Area

Current Climate Change Policy and Outlook for Greater London ......................................14

Data

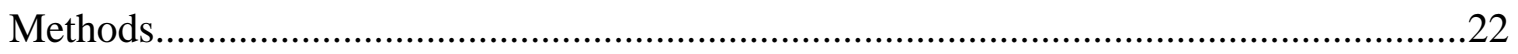

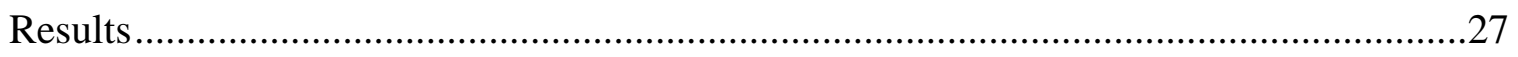

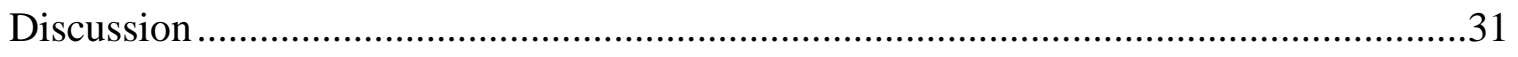

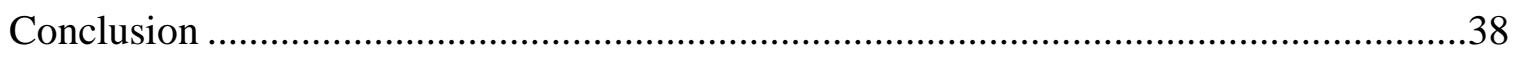

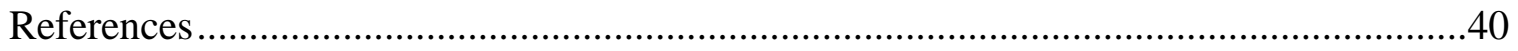

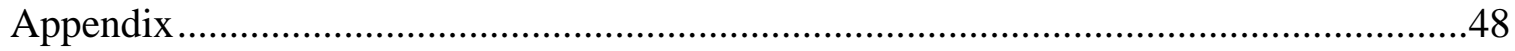

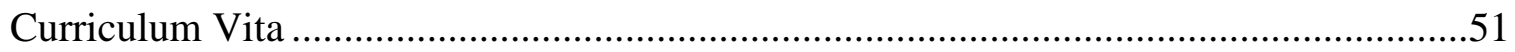




\section{LIST OF FIGURES}

1. Defense Levels of Thames Barrier ....................................................................

2. Thames Barrier Closures Since 1983..............................................................10

3. Population Density of Greater London 2011 per Lower Layer Super Output Area ..

4. Key European Regional Risks from Climate Change and the Potential for Reducing Risks Through Adaptation and Mitigation ............................................14

5. Thames Estuary 2100 Decision Pathways ………………………………….......16

6. The Thames Gateway Initiative in London and Greater South East ......................17

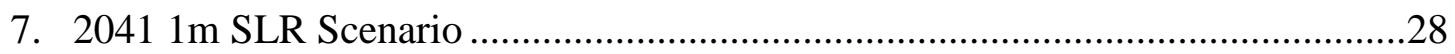

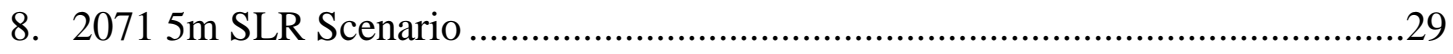

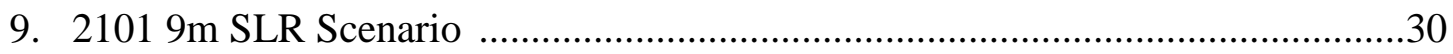




\section{INTRODUCTION}

This study focuses on certain aspects of potential social consequences of the climate change affecting areas of Greater London, United Kingdom, over the course of the $21^{\text {st }}$ century. In recent decades, changes in climate have caused impacts on natural and human systems on all continents and oceans, with evidence strongest regarding natural systems (IPCC 2014a). Climate change refers to a shift in a climate state that is quantifiable by changes in the mean and/or variability persisting for an extended period, typically decades or longer (IPCC 2014a). The attraction to hazards-based research stems from the ongoing discourse within the field of climate change and the projections of some advanced climate models predicting a hazardous future (Hansen et al. 2016).

Hazards are defined as potential physical events, trends, or environmental impacts that may cause damage, loss, or disruption to human and/or natural systems (IPCC 2014a). The hazard of interest to this study is sea-level rise (SLR), where recent climate models suggest that meter-scale SLR is practically unavoidable over the $21^{\text {st }}$ century and beyond if greenhouse gas emissions grow at the current pace, resulting in excess heat energy being pumped into the oceans (Hansen et al. 2016). It is doubted that the current $2^{\circ} \mathrm{C}$ target limit of increase in mean global temperatures, set in the 2016 Paris Agreement will be sufficient to stave off unexpected rise in sea levels. Thus, it appears that many coastal cities in the low-lying areas could be subjected to SLR of higher magnitude than is expected from a $2{ }^{\circ} \mathrm{C}$ increase to mean global temperatures (Hansen et al. 2016). 
In the 21st century SLR projections by the International Panel on Climate Change (IPCC), low-lying areas will increasingly experience adverse impacts such as coastal flooding and coastal erosion (IPCC 2014a). Meanwhile, it is projected that population growth, economic development, and urbanization will significantly increase pressure on coastal regions subjecting local population and infrastructure to further exposure of coastal flooding risks in the coming decades (IPCC 2014a). For example, McDougal (2010) suggests that some coastal regions in the United Kingdom have begun to feel the social effects of anticipated SLR.

Some of the most unpredictable consequences of SLR appear to be those related to population redistribution. The SLR may affect social aspects directly by physically forcing people to relocate, but also indirectly via economic and political influences (Black et al. 2011). Accommodating displaced peoples has already proven to be a difficult situation in the modern world, given the observations regarding the current refugee crisis in the Middle East (Wolff 2015). Tacoli (2009) states that by 2050, between 200 million and 1 billion people will be forced to relocate due to climateinduced stress alone. However, these figures are global estimates and not entirely contributable to SLR. The IPCC (2014a) agrees that climate change over the $21^{\text {st }}$ century is projected to increase displacement of people by migration as a potentially effective adaptation strategy. This study focuses on the effects of SLR-induced coastal inundation on Greater London, UK, with a view to quantifying the SLR's impact on populations at risk from a regional perspective.

Based on evidence from available previous studies and including projected SLR scenarios for London, UK, the formal research question could be described in two parts 
as follows. How adequate is the current level of hazard mitigation preparedness towards SLR and coastal inundation projections in Greater London, UK for the $21^{\text {st }}$ century? And what impacts will these have on regional population risk? With these research questions in mind, the hypothesis is that Greater London's current level of hazard mitigation is inadequate to withstand the projected future SLR scenarios and will result in increased risk to populations at a regional level throughout the $21^{\text {st }}$ century.

The objectives of the study are to determine the aerial extent of inundation within the Greater London area and its potential regional population redistribution effects. The results of the research are expected to provide some recommendation with regard to adaptation and mitigation strategies for United Kingdom governmental authorities to deal with this complicated scenario.

The significance of this project is paramount if the stated Hansen et al. (2016) projections are even possible within the $21^{\text {st }}$ century. Greater London is home to over 8 million people including a physical evidence of rich cultural history and stands to lose enormously in the wake of coastal inundation. As demonstrated by Hurricane Katrina and numerous other climate impacts, actions taken before an extreme weather event are more effective and less costly than retrospective actions (Nickson 2011). Performing this study highlights exactly what areas of Greater London are most at risk while offering insight towards preventative measures if authorities begin planning accordingly in the short and near terms. 


\section{BACKGROUND}

The seminal study by Hansen et al. (2016), triangulates evidence from atmosphere and ocean modeling, paleoclimate data, and modern observations of ongoing climate change. Through an aggregation of methods, Hansen et al. $(2016,3762)$ argue that if humanity continues the status quo of fossil fuel consumption, it will be "impossible to avoid large-scale ice sheet disintegration with SLR of at least several meters." This assertion by Hansen et al. (2016), who labeled as 'prescient' by his peers (e.g. Milman 2016), is grounded in the evidence discussed in the landmark study. Hansen et al. (2016) serves as the premise of this study drawing from its 323 cited references to earlier works enhancing the scope of understanding of SLR related to climate change.

The paleoclimate data shows a $+6-9 \mathrm{~m}$ SLR on a few occasions in various times and locations, with onset sometimes as rapid as an 'ecological period' (several decades), most recently occurring during the Eemian interglacial period (130,000-115,000 years ago). SLR of this magnitude was cited from several sources of academic literature, nearly all of which occurring during periods where global temperatures were less than $2^{\circ} \mathrm{C}$ above preindustrial levels. Hansen et al. (2016, 3780) suggest that this "rapid lateEemian SLR relates to our expectation of likely near-future events if rapid global warming continues." The paleoclimate data supporting the $+6-9 \mathrm{~m}$ SLR was drawn from Eemian sea level site data (limestone platforms and coral reefs), strong late-Eemian storms in the Bahamas and Bermuda (megaboulders, runup deposits, and chevron ridges), 
North Atlantic Ocean sediment cores, and Earth orbital patterns in the late Eemian period.

The biggest difference between the Hansen et al. (2016) argument compared to the models discussed in an earlier work stems from the recent shift to favor exponential over linear responses of SLR to ice sheet melting. Hansen et al. (2016) argues that ice mass loss from the most vulnerable sea ice will lead to exponential SLR as compared to the more conservative, conventionally cited, linear responses. Ocean models that offer linear responses are too diffusive and as a result, generate an unrealistically slow response time (Hansen et al. 2016). The basis in linear models is that ice-melt doubling times of 10, 20 or 40 years will yield multi-meter SLR within 50,100 or 200 years, while recent ice melt doubling times are near the lower end of the 10-40-year range. Pollard, DeConto, and Alley (2015) even found that by simply adding hydrofracturing and cliff failure into an ice sheet disintegration model, simulated SLR increased from $2 \mathrm{~m}$ to $17 \mathrm{~m}$ in response to $2^{\circ} \mathrm{C}$ ocean warming while the climate response time changed from several centuries to decades. From their point of view, a rapid SLR in the $21^{\text {st }}$ century is a given, rather than a possibility.

With numerous concerned countries and world bodies clamoring to cap global warming at $2^{\circ} \mathrm{C}$ increase from preindustrial temperatures (Rogelj et al. 2016), Hansen et al. (2016) showed that this temperature limit is not enough to prevent significant SLR. The pressure mounts considering that global authorities from the 194 signatory countries that signed to the Paris Agreement (United Nations 2016) are already having difficulties implementing the approved measures. Under the Trump administration, the United States has already declared to pull out of the Paris Agreement by 2020 although some 
cities, regions, businesses, and other social actors are attempting to take matters into their own hands by implementing their own carbon reductions (Watts 2017). Goals of the Paris Agreement will be difficult to deliver on as it was founded on a voluntary basis without any legally binding caps to emission limits and without mechanisms to impose actions (Mahapatra and Ratha 2017). Worse, the scientific reasoning of the Paris Agreement is potentially flawed as the combined effect of pledges made still leaves the world on track for $+3.4^{\circ} \mathrm{C}$ by 2100 (Fekete et al. 2017). To put in perspective the negotiated Paris agreement warming limit of $+2.0^{\circ} \mathrm{C}$, consider that global temperatures have already increased by nearly $1.0^{\circ} \mathrm{C}$ above pre-industrial levels (Hawkins et al. 2017). Even if carbon emissions completely stopped tomorrow, we are still locked into another $0.3^{\circ} \mathrm{C}$ of committed warming without any further increases in radiative forcing (Mauritsen and Pincus 2017). The increase corresponds to current atmospheric levels of over 400 parts per million (ppm) $\mathrm{CO}_{2}$ (NOAA 2017) in comparison with 280ppm maximum before 1880 (Rummukainen 2016) with levels of at least 550ppm projected by the end of this century (Hoffert et al. 2002). This follows from the rate of increase accelerating since measurements began, from around $0.7 \mathrm{ppm}$ per year in the late $1950 \mathrm{~s}$ to 2.1 ppm per year during the last 15 years (NOAA 2013).

$\mathrm{CO}_{2}$ is often mentioned as the "control knob of climate change" (Lacis et al. 2010, 358). This level would need to be lowered below 260ppm to produce a global climate where sea levels could theoretically drop several meters below modern levels (Hansen et al. 2016). Slow to leave, once $\mathrm{CO}_{2}$ has been introduced to the climate system, whether by humans or through natural forcing agents (e.g. volcanic activity), it remains there in the order of 100,000 years before full removal by weathering (Archer 2005). According 
to Archer and Brovkin $(2008,283)$, "The largest fraction of the $\mathrm{CO}_{2}$ recovery will take place on time scales of centuries, as $\mathrm{CO}_{2}$ invades the ocean, but a significant fraction of the fossil fuel $\mathrm{CO}_{2}$, ranging in published models in the literature from $20-60 \%$, remains airborne for a thousand years or longer." With atmospheric $\mathrm{CO}_{2}$ showing no signs of abatement due to continued combustion of fossil fuels and an elongated residence time, the Earth appears committed to continued warming in the $21^{\text {st }}$ century.

With the 'control knob' set to explosive growth of $\mathrm{CO}_{2}$ combined with a SLR response rate to temperature fluctuations of within a century, rapid SLR will be initiated (Grant et al. 2012). Peak temperatures during the Eemian period, when the Earth last saw +6-9m SLR, were only a few tenths of a degree higher than today (Hansen et al. 2016). We should also bear in mind that two thirds of the projected warming (and likely emissions) occurred after 1975 (Hansen et al. 2010), meaning the current climate situation has been in the making over roughly the last +40 years. Furthermore, this study projects this trending combination of increased $\mathrm{CO}_{2}$, global mean temperatures, and SLR out another +80 years, along with human population and its increased vulnerabilities. If 400ppm $\mathrm{CO}_{2}$ has already led us to $+1.3^{\circ} \mathrm{C}$ from preindustrial times, then it is not hard to imagine at least $+2.0^{\circ} \mathrm{C}$ under 550ppm $\mathrm{CO}_{2}$ and if Hansen et al.'s (2016) projections are correct, +6-9m SLR this century. 


\section{STUDY AREA}

The SLR is one of the most tangible effects related to climate change, and also the most directly connected to forced migrations as inundated areas become uninhabitable. The United Kingdom, as well as its Northern European neighbors, is considered a "pull" country regarding future European climate change migratory scenarios where much of the moving population will be "pushed" from the Mediterranean Basin towards these northern destinations (Piguet and Laczko 2014). With the recent Brexit decision, this new variable may further restrict options of where climate refugees may go both within and outside of the United Kingdom.

London, UK prevailed as a suitable study area of choice for several reasons. First, it is a global megacity that while not directly on a coastline, it is affected by tidal processes of the River Thames (Bowen 1972). This makes London unique compared to several other more exposed cities (e.g. Tokyo, Miami, and Mumbai) as it is mostly concerned with perturbations stemming from fluvial inundation of the River Thames. Also, being a globally connected, historically thriving city, it has sufficient assets to proactively invest to preempt or mitigate the effects of SLR. In fact, the local authorities have already taken steps to protect the city against tidal flooding with the construction of the Thames Barrier in 1982 (Horner 1987), alongside over $300 \mathrm{~km}$ of fixed defenses and numerous smaller structures which came after the catalyst event of the 1953 flood (Lavery and Donovan 2005). The Thames Barrier consists of ten moveable gates of 
differing sizes strung across the river, six of which are navigable for the city's water traffic, and are supported between concrete piers containing the operating and control equipment necessary to create a continuous steel wall facing downriver to hold back surges (Horner 1987). The Thames Barrier was originally designed to provide protection until 2030 (Horner 1987) as the initial plan took account of early historical rates of SLR which were largely driven by natural subsidence rather than climate change (Ranger, Reeder, and Lowe 2013). However, The Environment Agency (2012) extends confidence that the Thames Barrier will remain useful until potentially 2060. Maximum defense height for the Thames Barrier can be seen in Figure 1. The Thames Barrier is the second largest moveable flood barrier in the world (Environment Agency 2017b).

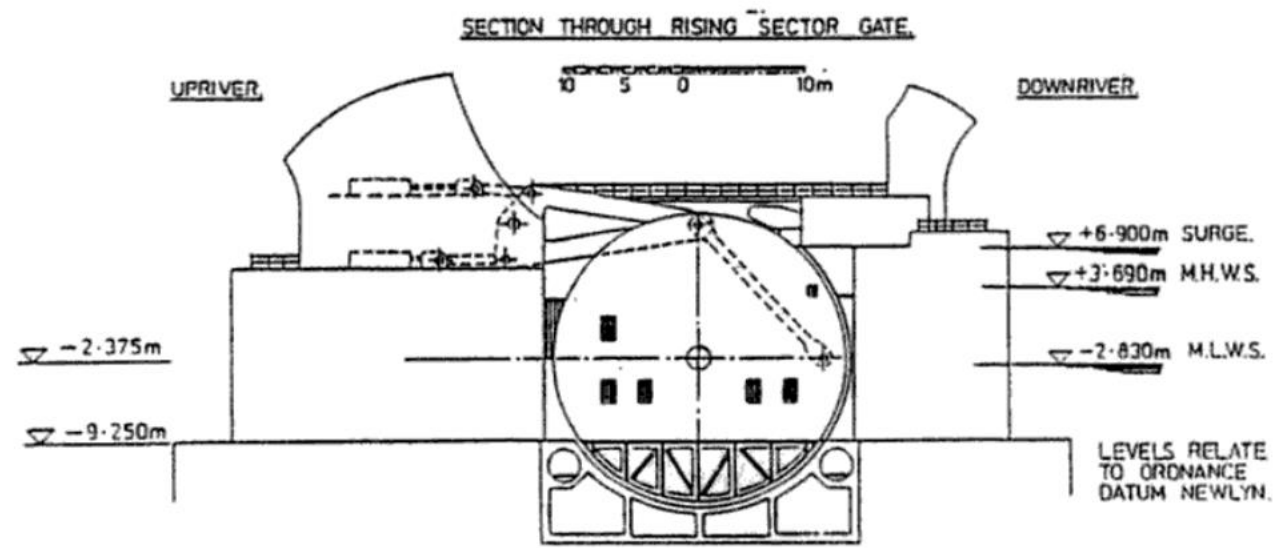

Figure 1. Defense Levels of Thames Barrier (Adapted from Lewin and Lavery 2002)

The Thames Barrier has been closed 179 times since it began operation in 1982 to protect against a combination of tidal and fluvial flooding (Environment Agency 2017b), averaging five closures annually. An increasing trend of barrier closures has occurred in every decade since implementation and can be seen in Figure 2. Considering whether 
London needs additional protection is urgent and according to Lewin and Lavery (2002, 200), "preliminary estimates indicate capital investment of the order of $£ 4$ billion may be required and major municipal works of this type could take up to the 30 years to plan, design, and obtain approvals." Earlier proposals were considered for a second barrier downstream at Sheerness but nothing materialized due to increasing developmental costs (The Engineer 2003).

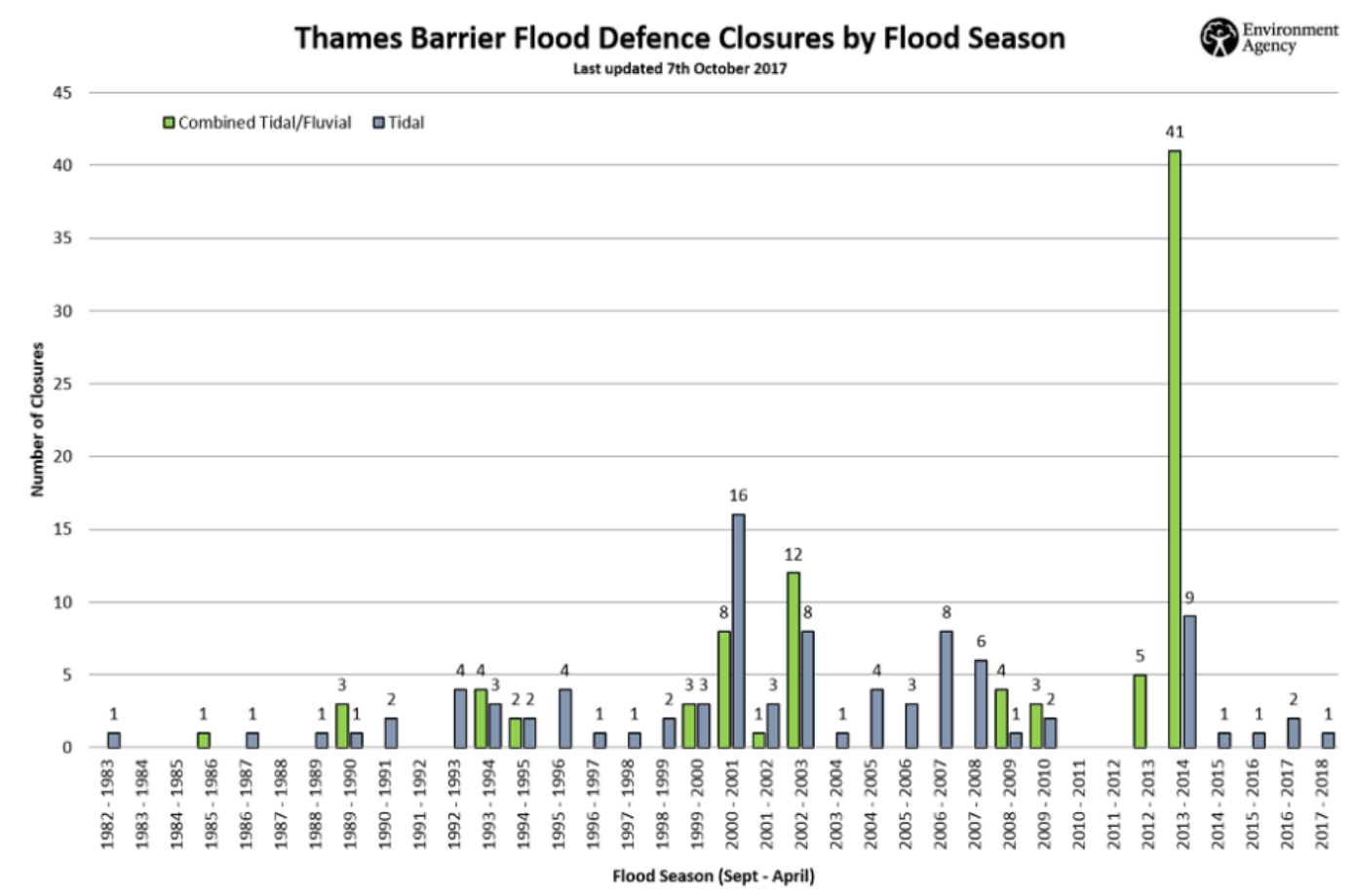

Figure 2. Thames Barrier Closures Since 1983 (Adapted from Environment Agency 2017b)

The County of Greater London was created on 1 April 1965 through the London Government Act 1963 (Travers 2004). Greater London itself consists of 33 boroughs; 12 inner boroughs which constitute the County of London, 20 outer boroughs which act as the perimeter of Greater London, and one for the centrally located City of London itself 
(Greater London Authority 2015). The County of Greater London encompasses the full study area of interest.

Much of central London has been developed on low-lying marshland alongside the tidal River Thames (Lavery and Donovan 2005). As such, London is no stranger to flood events having experienced exceptionally high tides and large surges during 1928, 1953, 1973, 1978, and 1996 (Lavery and Donovan 2005). Adding to London's environmental issues as a uniquely complex study area is its currently rising water table (Kennedy, Cuddihy, and Engel-Yen 2007), as well as potential hydrologic inundation due to other natural processes such as groundwater flooding via groundwater rebound (Jones 2007). These complicating factors mean that the city of Greater London and its constituents must manage inundation from both above and below the surface, perhaps simultaneously (Macdonald et al. 2011). This study will not focus on groundwater flooding but it is a relevant factor worthy of mention and may complicate Greater London's future hazard potential.

Further complicating this situation is the projection of the United Kingdom to grow beyond 77 million people by 2050 (McDougall 2010), with a significant portion of that residing in London. UK population is at its largest ever at 65 million (Office for National Statistics 2017) while the current population density of England and Wales combined is $371 / \mathrm{km}^{2}$ (McGregor 2012). This figure jumps to $5200 / \mathrm{km}^{2}$ for Greater London but the value drops to between 222 to $500 / \mathrm{km}^{2}$ outside of urban areas (McGregor 2012). Still, this number pales in comparison with Bangladesh which boasted a national density of $976 / \mathrm{km}^{2}$ and $8229 / \mathrm{km}^{2}$ in the capital of Dhaka in 2011 (BBS 2015). The region of Greater London covers $1,570 \mathrm{~km}^{2}$ (Watson 2009) and had an aggregate 
population of $8,174,000$ at the 2011 census (McGregor 2012). It is the smallest but most densely populated English region (Watson 2009). The most recent census (2011) population density map of Greater London at the Lower Layer Super Output Area (LSOA) is shown in Figure 3. LSOAs function as the UK equivalent to US census block groups.

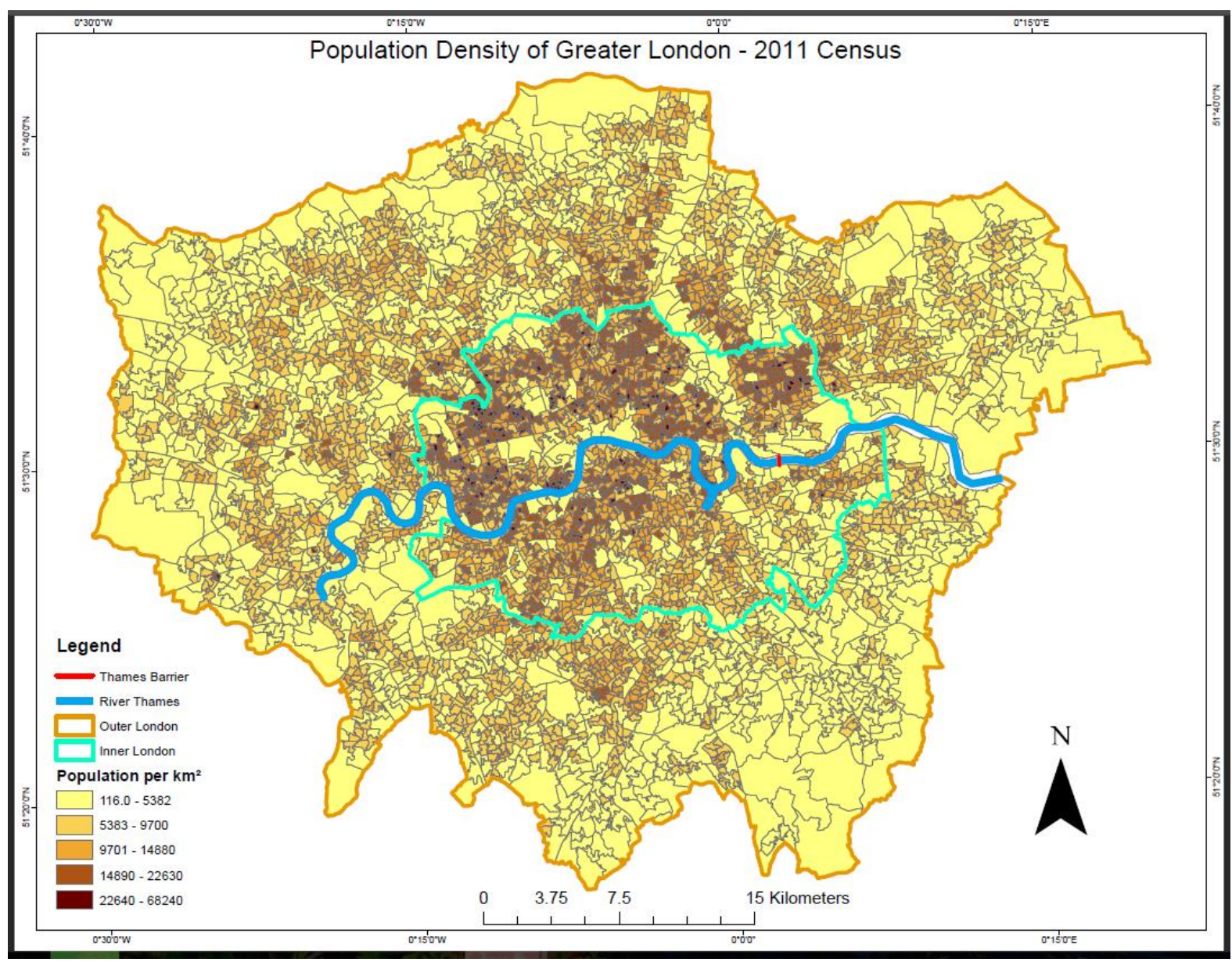

Figure 3. Population Density of Greater London 2011 per LSOA (Office for National Statistics 2016; Office of National Statistics 2011b)

Along with investment in mitigation measures, much research regarding hydrological hazards in the London area has been published in recent decades (e.g. Parker 1999). The worldwide number of scientific publications available for assessing climate change impacts, adaptation, and vulnerability more than doubled between 2005 
and 2010 (IPCC 2014a), and this study focuses on applying the published results to Greater London. 


\section{CURRENT CLIMATE CHANGE INSTITUTIONAL POLICY AND OUTLOOK OF GREATER LONDON}

The IPCC (2014a) has identified a range of impacts as the key risk matrix affecting Europe during the $21^{\text {st }}$ century with precipitation and SLR as the main climactic drivers. In the United Kingdom, risk of death, injury, or disrupted livelihoods in lowlying coastal zones and large urban populations due to storm surges, coastal flooding, and SLR are the main concerns (IPCC 2014a). The good news is that the risk is relatively low in the present and near terms and much of the potential damages are preventable in the long term with careful and precise adaptive measures (IPCC 2014a). These risks, adaptation issues, and associated climactic drivers are represented in Figure 4.

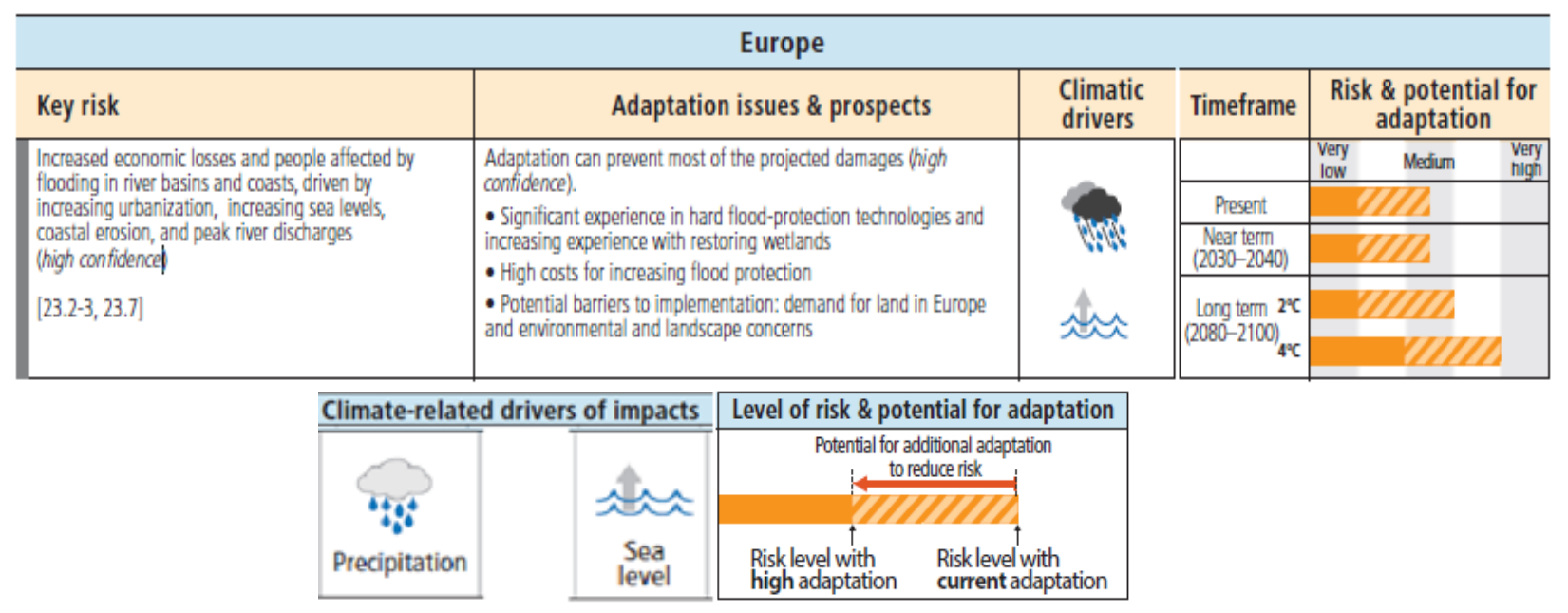

Figure 4. Key European Regional Risks from Climate Change and the Potential for Reducing Risks Through Adaptation and Mitigation (Adapted from IPCC 2014a, 22)

Organizations bridging science and decision making, including climate services, play a key role in the communication, transfer, and development of climate-related 
knowledge (IPCC 2014b). The key institution that fits this role in the United Kingdom is The Met Office. As part of the Environment Agency (EA), the Met Office (MO) is the official source of meteorological information in the United Kingdom (Met Office 2011). Generally, its role lies in the response spectrum of hazards and mainly focuses on short term meteorological forecasting of weather events. However, as part of the EA's plan to project an outlook for the $21^{\text {st }}$ century and beyond, the MO worked with other key organizations to help produce the Thames Estuary 2100 Plan (TE2100) (Environment Agency 2012).

TE2100 was developed to improve London's preparedness for flooding and reduce the consequences of a tidal flood in the unlikely event it happens while recommending what actions the EA and other entities will need to take in the short term (2040), medium term (2055) and long term (2100) (Environment Agency 2012). TE2100 identifies the main tidal flood risk to Thames estuary communities stems from the sea and projects water levels in the estuary to rise between $20 \mathrm{~cm}-90 \mathrm{~cm}$ and up to a maximum of $2 \mathrm{~m}$ over the next century due to thermal expansion of the oceans and additional water from melting glaciers and ice sheets caused by climate change (Environment Agency 2012). Even with these projections, only passing references to improve current defenses and/or build a new barrier are acknowledged in TE2100. This comes as a significant reduction to their previous projections and assumes faith in the Thames Barrier providing enough protection to sustain London through at least the next 50 years. I posit that based upon Hansen et al.'s (2016) research, these estimates are far too low and more flood mitigation infrastructure is imperative. TE2100 decision pathways for each SLR scenarios are listed in Figure 5. 


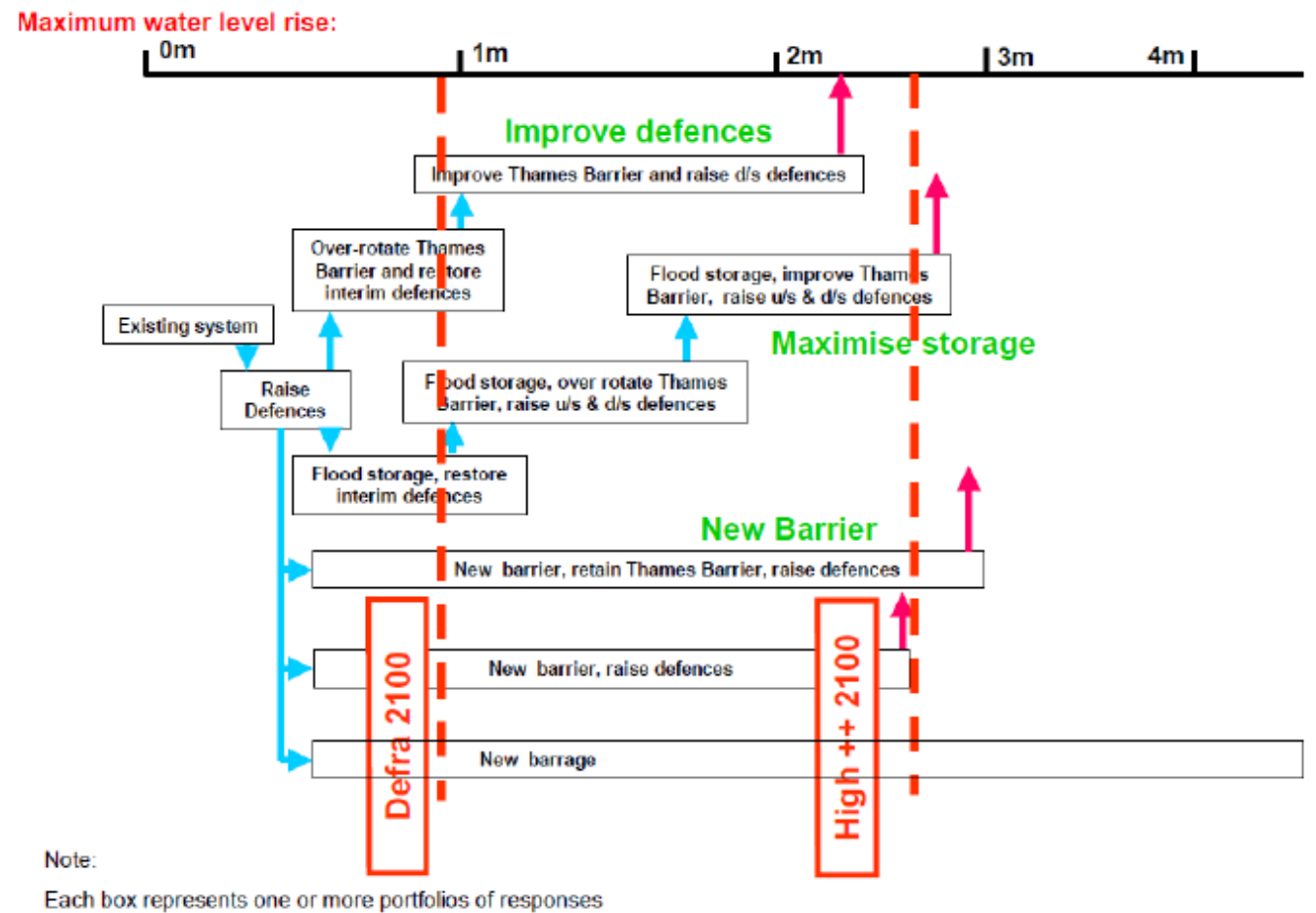

Figure 5. TE2100 Decision Pathways (adapted from Nickson 2011, 7)

Increasing the difficulty of managing the estuary's flood risk, The Thames

Gateway regeneration initiative began in 1994 to spur substantial growth and development throughout the area and has been a local priority ever since (Lavery and Donovan 2005). These developments will fundamentally change the built footprint in the Thames Estuary flood plain, and projects to be in place for at least the next 100 years, presenting the challenge of planning future defense against the uncertainty over climate and environmental change (Lavery and Donovan 2005). The conservative SLR projections of TE2100 coupled with the commitment to development in the Thames Gateway initiative potentiates the vulnerability of Greater London if projections closer to Hansen et al.'s (2016) work come to fruition. A spatial representation of the Thames Gateway initiative can be seen in Figure 6. 


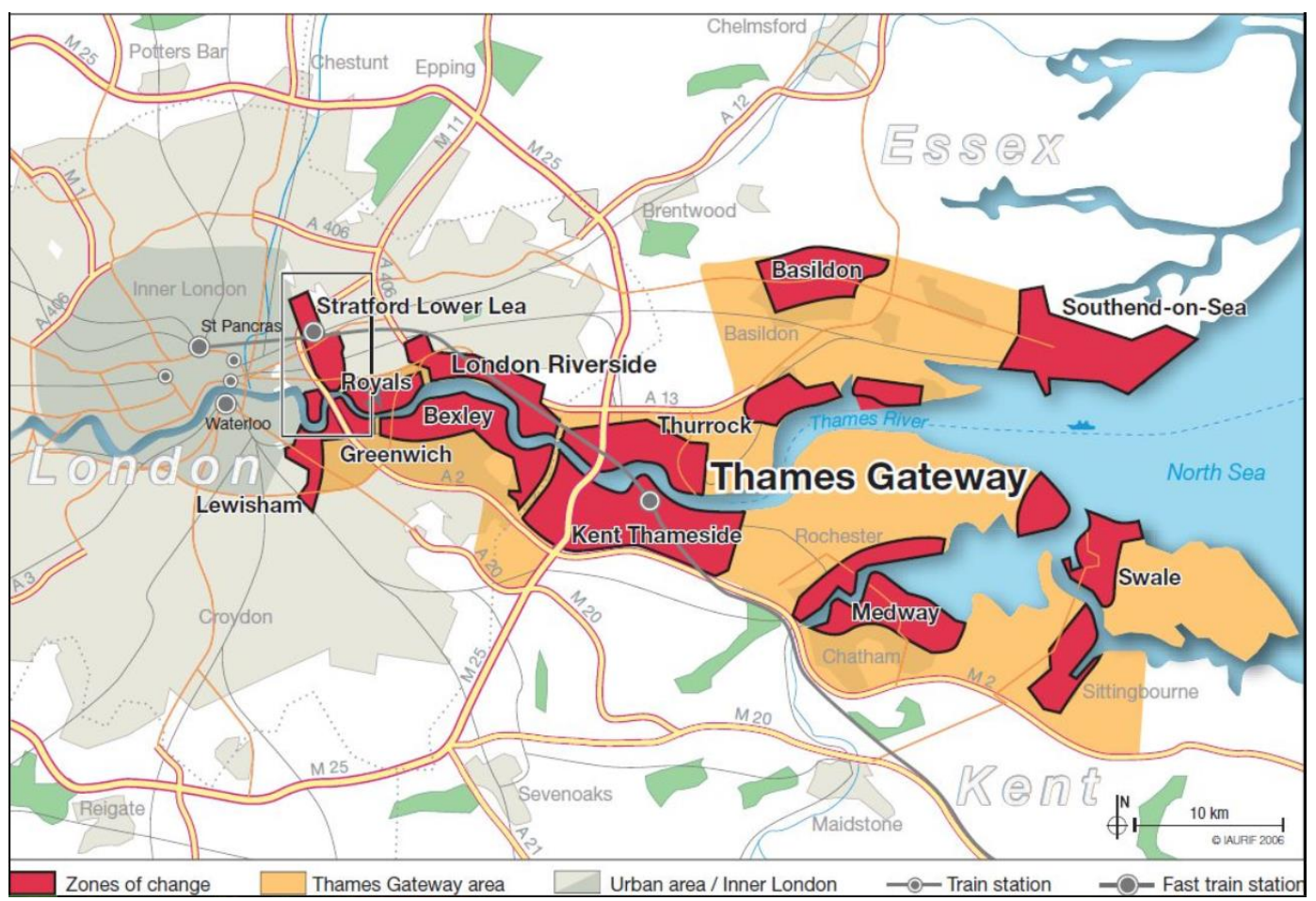

Figure 6. The Thames Gateway Initiative in London and Greater South East (Adapted from Institute of Planning and Urban Development of the Ile-de-France Region 2007) 


\section{DATA}

Population density for Figure 3 was calculated using 2011 census aggregate data and boundaries (Office for National Statistics 2016; Office of National Statistics 2011b) highlighting the current population distribution per lower layer super output area (LSOA); this is the most recent census conducted in the United Kingdom. LSOAs were designed by the Office of National Statistics in 2004 to improve the reporting of small area statistics and will be a key geography in future censuses (Office for National Statistics n.d.). LSOAs function similarly to the census block group boundaries that are used in the U.S. As represented in Table 1, each polygon contains a population of between 1000 and 3000 with a minimum of 400 and a maximum of 1200 households (Office for National Statistics n.d.). The shapes of these polygons are updated each census as the underlying population totals adjust accordingly (Office for National Statistics n.d.).

Population and household minimum and maximum thresholds for SOAs in England and Wales

\begin{tabular}{rrrrr}
\hline Geography & $\begin{array}{r}\text { Minimum } \\
\text { population }\end{array}$ & $\begin{array}{r}\text { Maximum } \\
\text { population }\end{array}$ & $\begin{array}{r}\text { Minimum number of } \\
\text { houseolds }\end{array}$ & $\begin{array}{r}\text { Maximum number of } \\
\text { households }\end{array}$ \\
\hline LSOA & 1,000 & 3,000 & 400 & 1,200
\end{tabular}

Table 1. Polygon Parameters for LSOA (Adapted from Office for National Statistics n.d.). 
Future population estimates for milestones of 2041, 2071, and 2101 were also projected at the LSOA level. These are extrapolated with a location specific aggregated growth rate combined from previous censuses (1971-2011) for each LSOA polygon. These demographics are overlaid on top of a digital elevation model (DEM) accounting for the regional topography of the study area.

A high-resolution DEM of 50m accounting for basic flood mitigation infrastructure, ascertained from the Ordinance Survey Limited (OSL 2017), is utilized providing the most accurate representation of current coastal flooding preparedness in Greater London. This DEM is equipped with a grid spacing of 50m, covers the entirety of Great Britain, and is available in tiles of $10 \mathrm{~km} \times 10 \mathrm{~km}$ (Yunus et al. 2016). The required tiles for Greater London were downloaded from the OSL (2017) and clipped to contain only the study area.

Attempts to obtain a higher resolution DEM were explored but ultimately proved unsuccessful as all other options were cost prohibitive. Higher resolution DEMs were available at significantly lower costs to all UK based institutions. A similar outcome was found in a recent study by Yunus et al. $(2016,15)$ regarding SLR in London, where they tested various DEM resolutions to determine accuracy and concluded that the OSL's 50m DEM used in this study, "provides much better estimates of the total flooded areas despite the low horizontal resolution." Yunus et al. $(2016,15)$ further went on to recommend, "using the freely available 50m open (OSL) DEM data for inundations studies in the UK, if no high-resolution data are available." Hence, the decision to take the cost-effective approach in this study. 
A polyline feature representing the Thames Barrier was created with accurate coordinates. This provided an ability to juxtapose inundation vs safe pixels. Maximum defense height of 6.9m (T. Thorogood - UK Environment Agency, personal communication, email, March 8, 2017) was accounted for during SLR simulations to accurately estimate inundation coverage. This study assumes the Thames Barrier will not fail under the SLR scenarios unless it's upper limit is breached.

With the study frame spanning five decades, data acquisition came from various sources. Aggregate data was supplied by the Registrar General for England and Wales (1971a), the Office of Population Censuses and Surveys $(1997,2000)$ and the Office for National Statistics (2011a, 2016). Much of the boundary data came packaged alongside aggregate data but for 2001 and 2011 censuses, the data had to be acquired separately and later joined together. The Registrar General for England and Wales supplied one decade (1971b), the Office for National Statistics supplied the boundary data for two decades (2001, and 2011b), with the Department of the Environment (1981) and Ed Line Consortium (1991) supplying the others. Boundaries of Enumeration Districts (EDs) were sourced for years 1971-1991 while LSOAs were available for 2001 and 2011. This is because LSOAs were not developed for the 2001 census and EDs were the smallest unit of geography available for 1971-1991. All data, sources, and file types can be seen in Table 2. 


\begin{tabular}{|l|l|l|}
\hline Data Layer & Source & Type \\
\hline 1971 Census & Registrar General for England and Wales (1971a) & Aggregate \\
1971 Boundary & Registrar General for England and Wales (1971b) & Polygon \\
1981 Census & Office of Population Censuses and Surveys (2000) & Aggregate \\
1981 Boundary & Department of the Environment (1981) & Polygon \\
1991 Census & Office of Population Censuses and Surveys (1997) & Aggregate \\
1991 Boundary & Ed-Line Consortium (1991) & Polygon \\
2001 Census & Office for National Statistics (2011a) & Aggregate \\
2001 Boundary & Office for National Statistics (2001) & Polygon \\
2011 Census & Office for National Statistics (2016) & Aggregate \\
2011 Boundary & Office of National Statistics (2011b) & Polygon \\
DEM & Ordinance Survey Limited (2017) & 50m \\
Thames Barrier & Original creation of this study (2017) & Line \\
\hline
\end{tabular}

Table 2. Data Layers, Sources, and Types

All shapefiles shared the GCS OSGB 1936 Geographic Coordinate System and were projected into the OSGB 1936 British National Grid Coordinate System.

Boundaries acquired separately from associated aggregate data were joined to their accompanied CSV files in ArcMap 10.4.1 to represent each decade separately. Population density $\left(\mathrm{km}^{2}\right)$ for each decade was symbolized across five classes of graduated colors for sake of consistency. Classified ranges of population projections were normalized to 2011 default ranges in order to maintain consistency of visual representation throughout the study window. The most recent census occurred in 2011, while data prior to 1971 was not readily available leading to a sample size of five total decades. A larger data sample size was desired, however, five decades were the only empirical evidence with the necessary boundary data available. 


\section{METHODS}

The SLR simulation models considered three inundation scenarios, $1 \mathrm{~m}$ (conservative), $5 \mathrm{~m}$ (moderate), and $9 \mathrm{~m}$ (aggressive), based on projections for the $21^{\text {st }}$ century laid out in Hansen et al.'s (2016) work. These projections to global SLR were applied as if they happened exactly in the local context of Greater London. A realistic

global SLR scenario would likely experience regional differences and spatial variations in spite of the global average (Sallenger, Doran, and Howd 2012). These three scenarios were simulated across three, 30-year intervals of 2041, 2071, and 2101 to provide generational scope accounting for population growth. Decadal intervals were chosen to match the historical data used to determine growth rates. SLR simulations were applied in a progressive manner with $1 \mathrm{~m}$ to $2041,5 \mathrm{~m}$ to 2071 , and $9 \mathrm{~m}$ to 2101 , making the development of projections chronologically feasible. The selected intervals accommodated projected population change for Greater London at the LSOA level given a polygon specific, capped, aggregated growth rate formula.

According to Gotway and Young $(2002,632)$, "one of the most challenging areas in spatial statistics is the synthesis of spatial data collected at different spatial scales." Reibel and Agrawal $(2007,620)$ also stress incompatibility with spatial data in demography as, "the need to combine tract level population and subpopulation count data for the same region pertaining to two successive census enumerations, in order to compute an exhaustive and mutually exclusive set of tract level trends for the time 
interval." By disaggregating and reaggregating data, areal interpolation allows for the collection of data over one set of polygons and the prediction for another set of polygons (Krivoruchko, Gribov, and Krause 2011). With the available data from 1971-2011 projected at different geographies, areal interpolation was processed to normalize and maintain polygonal boundary consistency of decadal census data. This was done by areal weighting the population from the source polygons (which have the data), to the target polygons (that need the data), also known as the overlay method (Lam 1983). This method is best described by Hallisey et al. $(2017,2)$. "Areal weighting, often used to disaggregate populations, is a cartographic overlay method that preserves volume, meaning subdivided populations sum to the original population. Weights are determined from the size of the overlapping source and target zone areas." It is best represented by Hawley and Moellering (2006) in the formula:

$$
Z_{t}=\sum Z_{s} A_{s t} A_{s}
$$

where:

$\mathrm{Z}=$ value of the variable;

$\mathrm{A}=$ area;

$\mathrm{s}, \mathrm{t}=$ source and target zones, respectively

In this study, the area of overlap of the EDs (source zones) with the LSOAs (target zones) were divided by the area of the entire source zone to obtain the proportion, or areal weight, of the LSOA area within the target zone. The population for each ED was then multiplied by the areal weight for that target zone. Areal weighting also assumes that population count is homogeneously distributed within the source zones (Lam 1983). Considering how population is typically distributed within urban areas, this 
assumption is unlikely to be true. An attempt to account for this was taken by using the smallest unit of geography available for the target data (LSOA), representing the figures at the finest scale available while maintaining accuracy.

LSOA boundaries from 2011 were set as the target polygons and census data from 1971-2001 were the source polygons interpolated to this geographic unit. Future projections of 2041, 2071, and 2101 populations maintained the 2011 LSOA boundary target polygons for sake of consistency. No effort to reconfigure LSOA boundaries for future scenarios according to current UK census standards (see Table 1) was taken to maintain simplicity amongst projections.

Once boundaries were interpolated and population areally weighted for the 2011 polygon boundaries, decadal censuses from 1971-2011 were compared to generate a decadal growth rate. This was an attempt to generate empirical evidence of population change that could be projected throughout the remainder of the $21^{\text {st }}$ century. The amalgamated decadal growth grate was then applied to extrapolate population of each individual LSOA polygon for 2041, 2071, and 2101. This allowed for the geographic aspect of growth instead of simply applying a coarse, blanket projection for the entire city of London.

Due to the exponential growth of the initial results, growth potential was capped at a maximum of $100 \%$ for any single polygon per decade. Any cells expressing decadal growth rates greater than $100 \%$ were adjusted down to this value to accommodate the long-term projections of this study. While the empirical evidence showed several examples of this happening in a given decade between 1971-2011, the small sample size consisting of only the five available decades inflated growth rates for any polygon 
experiencing a large spike during this time frame. Along with this cap came a limit to total population of any LSOA expressing density equal to the maximum population density value from the 2011 data $(68,240)$. Population density was calculated by dividing projected population values by square kilometers (Pop. $\left.\div \mathrm{km}^{2}\right)$. The justification behind this assumes that population can only be so dense in a given area and therefore growth would eventually cease or shift to another location. Population density is already quite high in parts of London, so the densest LSOA from the most recent census (2011) represents a logical choice for the upper limit. This seemed fitting for the study area of Greater London where urban sprawl-like development advancing out into the suburbs and beyond the green belt away from the densest areas has long been the norm (Schoon 1998).

With these restrictions in place, a formula was setup to take the lowest value between the capped decadal growth rate projections or max population equating to the 2011 census density limit $(68,240)$ for each polygon. The outcome of this formula resulted in the formal population projections of each polygon for 2041, 2071, and 2101. This, again was done to create realistic projections without letting them grow exponentially, while allowing for the area of each polygon to maintain influence. Although an imperfect methodology, this allowed for the utilization of available empirical data while constraining and accounting for the most improbable and extreme outcomes.

A flat-water (bathtub) model concerning SLR was implemented keeping other variables constant such as fixed topography, coastal erosion, development of new coastal hazard infrastructure, etc. within the projected time frame. This constant provides a clear 
representation of the inundation Greater London will endure given their current mitigation infrastructure, assuming no further development of protective structures, while actual storms create uneven flooding in limited areas (Yunus et al. 2016). By using the flat-water model, demographics and inundation levels are the only changing variables over the time frame of study.

A Fill process was executed in ArcMap to smooth out both sinks and peaks creating a depressionless DEM. This allowed for a more accurate delineation of the floodplain by correcting errors due the resolution of the data or rounding of elevations to the nearest integer value (Jenkins and McCauley 2006). Tarboton, Bras, and RodriquezIturbe (1991) found that from 0.9 to $4.7 \%$ of the cells in non-SDTS USGS 30m resolution DEMs were sinks. The DEM used in this study utilized 50m resolution and had a sink count that was correspondingly higher.

Flooded areas were determined through a simple raster calculation procedure in ArcMap where the elevation of each DEM cell is compared against a predicted sea level and all cells with values lower than the predicted sea level are considered flooded (Yunus et al. 2016). A raster calculator output generating negative difference values show which areas face inundation given each of the three SLR scenarios. With raster calculations overlaid on top of demographic changes between each time interval, a risk population map was generated for each scenario. This simulation shows whether risk is increasing or decreasing and in which areas of the city over time. Once the SLR simulations had been processed, the resulting raster outputs were converted to polygons in ArcMap, their boundaries dissolved, and a final round of areal interpolation was performed to quantify the affected population inhabiting inundated polygons. 


\section{RESULTS}

The results of this study are covered in four parts. First, the totals from each projection are summarized in Table 3. Next comes individual inundation risk maps for each of the three projected SLR scenarios. Each set of results are individually outlined in their own section.

\begin{tabular}{|c|c|c|c|}
\hline Results & 2041 & 2071 & 2101 \\
\hline SLR Scenario & $1 \mathrm{~m}$ & $5 m$ & $9 m$ \\
\hline Projected Pop. & $10,493,854$ & $14,013,470$ & $18,149,016$ \\
\hline Inundated Pop. & 304,312 & 898,778 & $7,064,445$ \\
\hline Inundated Pop. Percentage & $2.89 \%$ & $6.41 \%$ & $38.92 \%$ \\
\hline Total Area $\left(\mathbf{k m}^{2}\right)$ & 1,570 & 1,570 & 1,570 \\
\hline Inundated Area $\left(\mathrm{km}^{2}\right)$ & 6.60 & 52.80 & 225.86 \\
\hline Inundated Area Percentage & $0.42 \%$ & $3.36 \%$ & $14.38 \%$ \\
\hline Unique LSOAs Affected & 99 & 216 & 1705 \\
\hline
\end{tabular}

Table 3. Population Projections and SLR Simulation Results for Greater London

Totals increased across the board for each successive scenario. As values increased in each decade, growth became exponential once decadal growth rates were sequentially applied to higher and higher figures. In the earlier scenarios, most of the population growth occurred throughout Inner London as this region had the highest growth momentum from the empirical census data. After much of Inner London met its capped density limit, the outer regions grew significantly more in the later scenarios. Inundated population increased at an exponential rate throughout each scenario as underlying population grew correlatively with inundation coverage. 
Note that each scenario is three decades removed from the last so differences in results may initially appear considerable. With this study spanning three projected scenarios throughout the $21^{\text {st }}$ century, each scenario is best described as individual maps in Figures 7, 8, and 9.

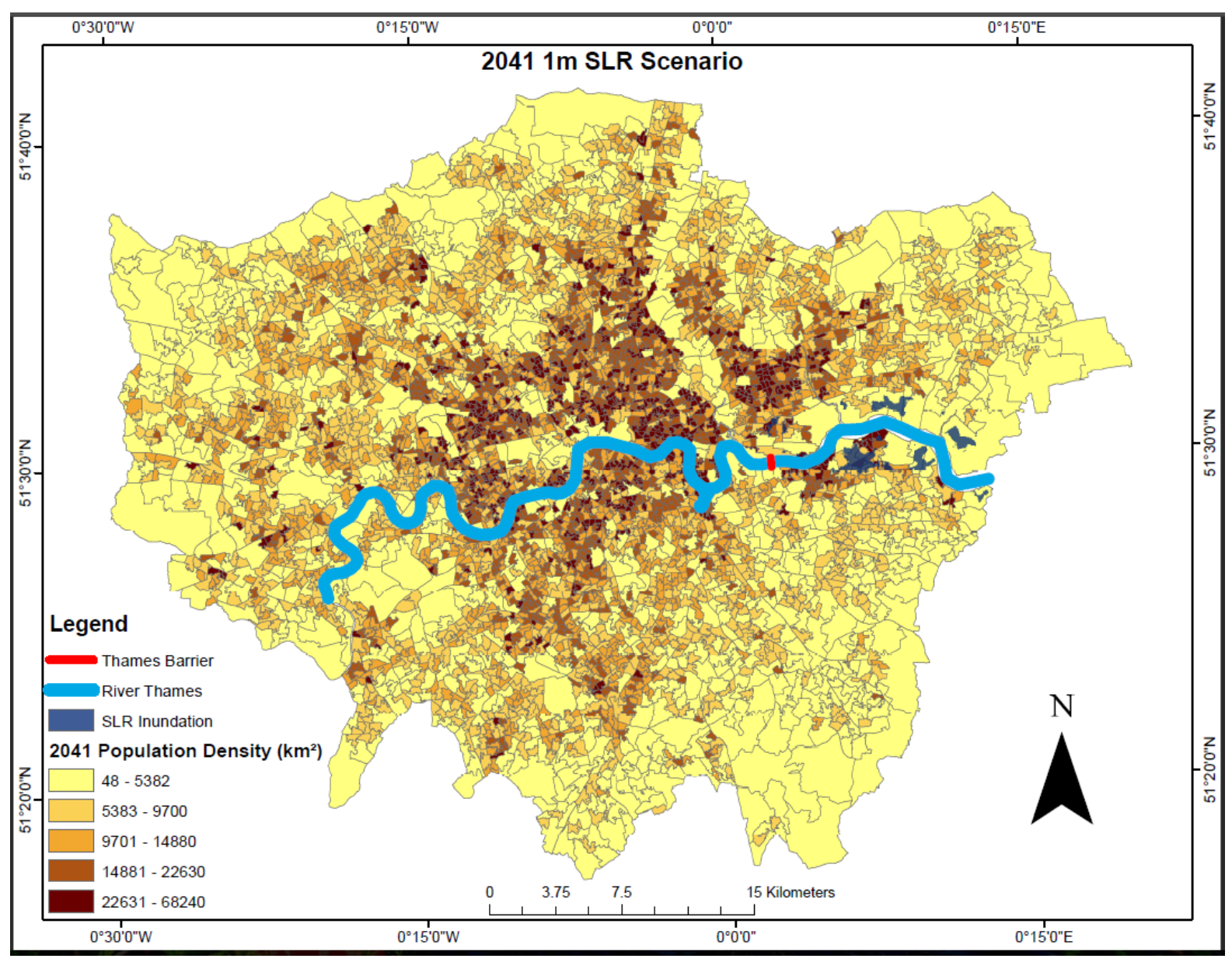

Figure 7. $20411 \mathrm{~m}$ SLR Scenario

For 2041, there was an absolute population gain of 2,292,663 leading to a $27.96 \%$ relative increase over 2011 figures. Inundated population was 304,312 for a modest $2.89 \%$ resulting in $6.60 \mathrm{~km}^{2}$ affecting a total of 99 different LSOAs. With a 50m DEM equipped at $1 \mathrm{~m}$ depth intervals, the vast majority of cells had elevation of at least $1 \mathrm{~m}$ and 
were not affected in 2041. As referenced above, the 2041 scenario showcased the largest growth pattern in Inner London.

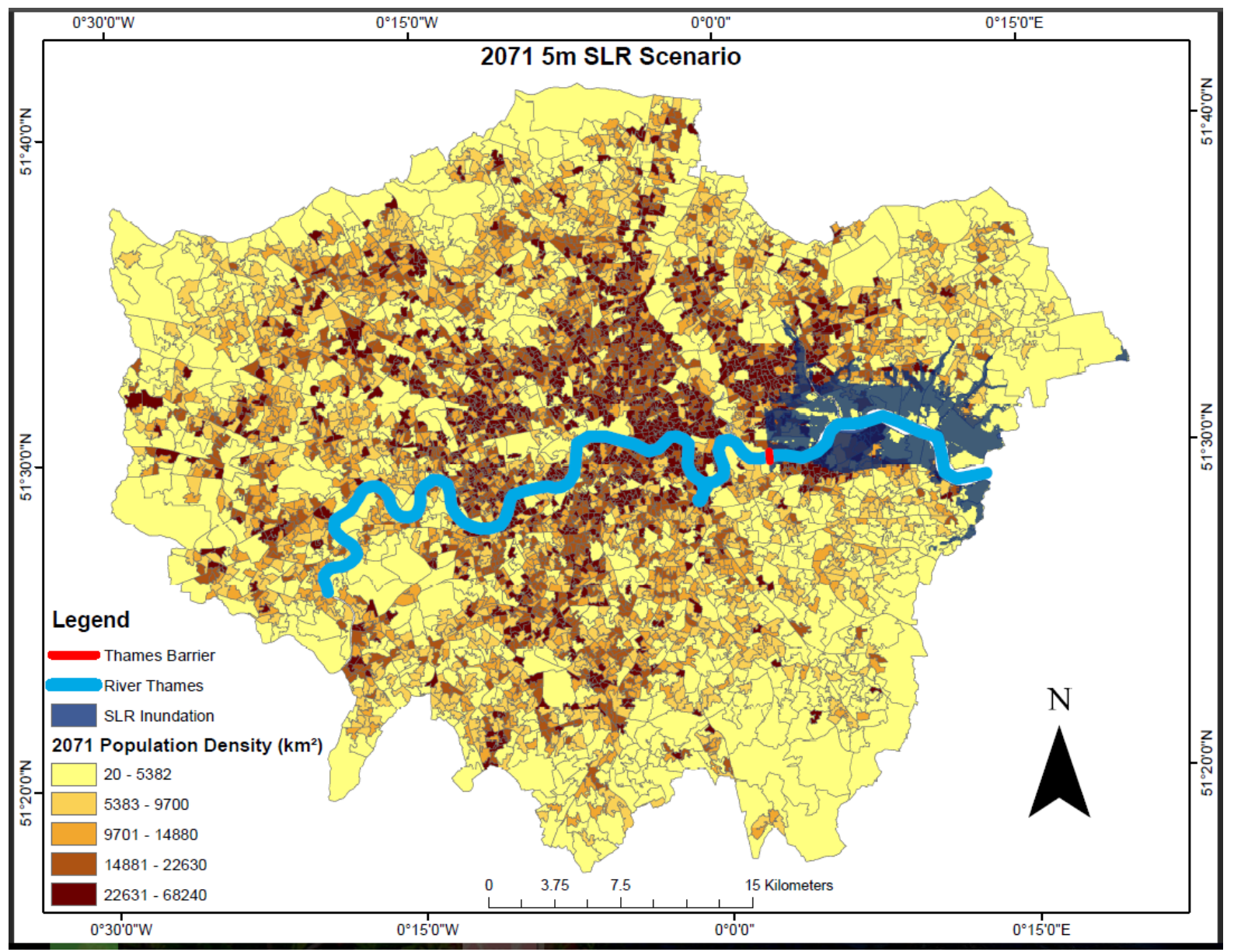

Figure 8. 2071 5m SLR Scenario

Significant impacts began to surface in projections for 2071. At 5m SLR, the Thames Barrier is expected to maintain integrity, thus leading to the stark juxtaposition of inundation versus safety along its front. With a $5 \mathrm{~m}$ simulation, the unprotected floodplain was mostly affected East of the Thames Barrier. Inundated population grew by 594,466 for a relative $195 \%$ increase over 2041 figures. $52.80 \mathrm{~km}^{2}$ were inundated spanning a total of 216 different LSOAs. 


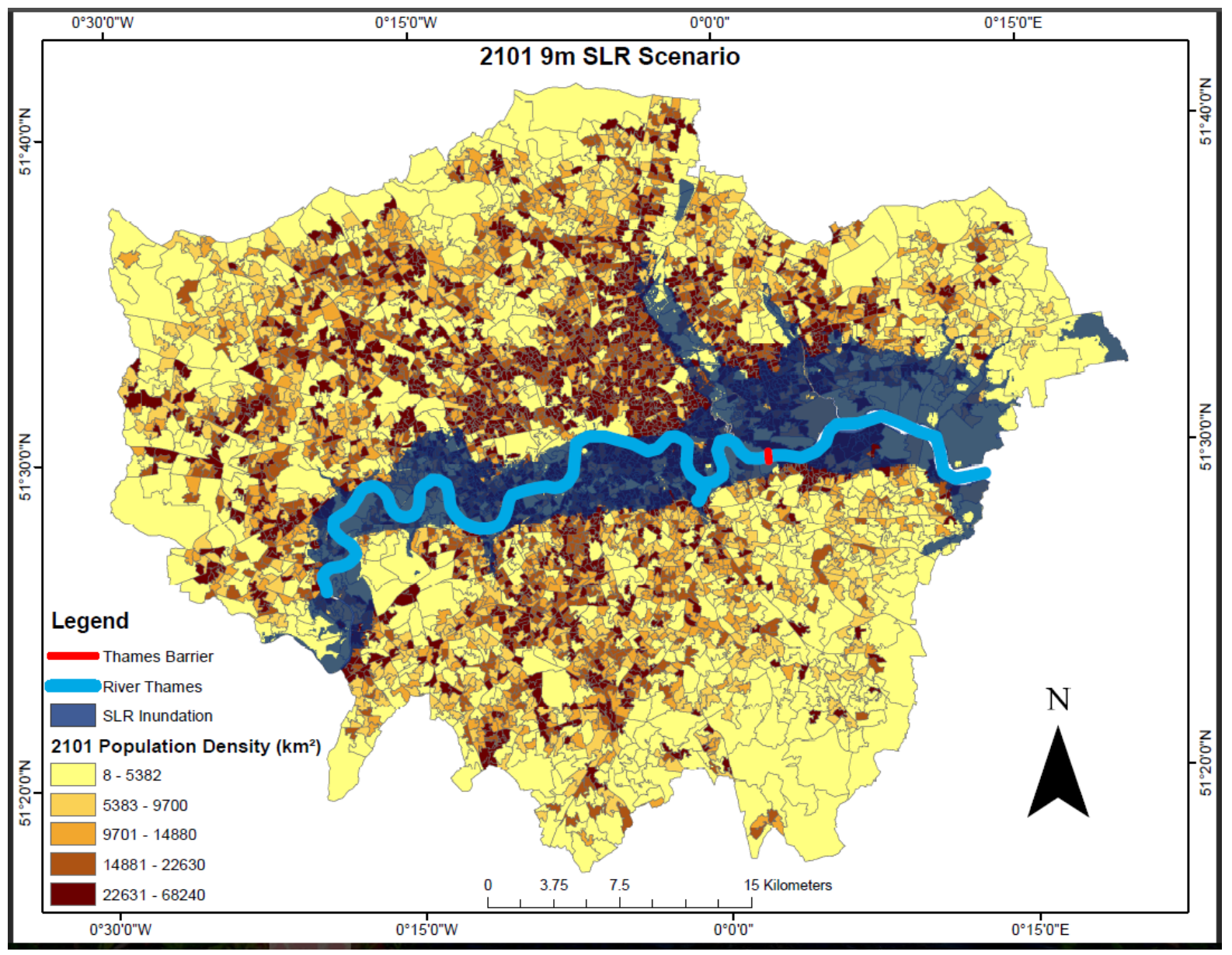

Figure 9. 2101 9m SLR Scenario

Finally, 2101 resulted in a total breach of the Thames Barrier and a significant increase to all variables. At eight decades removed from the initial 2011 figures, the aggregated growth rates indicated substantial momentum in this extrapolation. Much of the city appears extremely dense as total population stands a relative $121 \%$ more than the starting value of 2011 and $29.51 \%$ over 2071 . Inundated population grew by an absolute $7,064,445$ to $38.92 \%$ leading to a relative increase of $786 \%$ over 2071 , resulting in $225.86 \mathrm{~km}^{2}$ of inundation (14\% of Greater London) affecting 1705 total LSOAs at a percentage of $35.14 \%$. 


\section{DISCUSSION}

One of the most difficult aspects of studies that rely heavily on projections is dealing with uncertainty. Short-term projections often prove to be quite accurate, but the realities of attempting to predict what the world will look like nearly one hundred years from now is anything but certain. Many methods and models are available but only time will tell which was accurate. Hence the decision to use readily available empirical data for both population and SLR projections. From this perspective, results show consequences as dire as hypothesized, revealing potential options for mitigation such as migration, further flood infrastructure development and improvements, and policy reform to better prepare for the anticipated effects of SLR and coastal inundation.

Robust adaptation measures would be the core recommendation following the results of this study. Zoning laws specifically should be reconsidered as the current Thames floodplain is based on marks of a 1 in 100-year river flood level or the 1 in 200year tidal flood level (Environment Agency 2017a). If Hansen et al. (2016) projections come to pass, the type of flooding potential will exceed anything London has experienced in the last 100-200 years. London authorities have designated areas into a total of three zones with differing flood risk probabilities and development restrictions (Environment Agency 2017a), these should be reviewed going forward. Also, a call for proposals to build a new barrier should be fielded to generate momentum for future costs. If 30 years are required to plan, design, obtain approvals, and build a new barrier (Lewin and Lavery 
2002), it would be wise to start exploring options now to at least have a legitimate option and site on the table should significant SLR come to pass. Lastly, a formal relocation policy should be drafted in the event of significant SLR. As referenced in Table 3, projected inundated populations would present a serious strain for local and regional authorities to accommodate. SLR is different than acute flooding hazards as inundation caused by SLR would not clear on its own within the short-term, leading to permanently displaced populations. These are but a few adaption measures that could be explored for $21^{\text {st }}$ century climate change. Continued investment in applicable research and collaboration amongst concerned institutions and relevant parties must become a priority in order to build a resilient risk profile for the city of London as time moves forward.

As referenced in Figure 6, the Thames Gateway initiative is a project geared towards driving development in the Thames Floodplain east of the Thames Barrier. As Figures 7-9 suggest, much of the projected SLR stands to impact these areas hardest. If Hansen et al. (2016) projections prove to be accurate, this could lead to serious social and economic consequences for this area of London. This study built population projections upon empirical data (1971-2011), most of which occurred before the Thames Gateway initiative had significant developmental effects. The reality is likely that population stands to grow significantly more in the areas east of the Thames Barrier than this study could accurately predict. Perhaps, a revision or suspension of the Thames Gateway initiative and a second look into TE2100 would be wise, at least until plans for potential additional flood defenses materialize or uncertainty around the regional climate science is settled. 
Raising public awareness, access to knowledge, and incentivizing long-term thinking would provide a critical step forward in driving local initiatives for change. A worthy start would be through communicating with the IPCC's Terms Central for Understanding listed in Appendix A. These provide a foundation that is easy to infer and could present the basis of an approachable public policy to combat the future hazard potential of Greater London.

As described earlier in the data section, without the capped growth rate formula, projection results would have all been astronomically higher. Original simulations of population projections produced inflated results leading to further refining of formula mechanics eventually settling into the final, more realistic outcomes. Suggesting a London population of over 18 million may sound extreme within the $21^{\text {st }}$ century given its current figure of 8 million. However, some estimates project London to host 10 million by 2030 (Atkins Limited 2014), 13 million by 2050 (Lenati 2016), and 15 million by 2100 (Atkins Limited 2014). These external figures are not incompatible with the results developed in this study and pale in comparison to cities such as Lagos, Nigeria which is expected to approach a population of 100 million by 2100 (Hoornweg and Pope 2014). With continued urbanization, $66 \%$ of the global population will live in cities by 2050 (United Nations 2015). As this trend is expected to continue throughout the $21^{\text {st }}$ century, London does not stand to gain as much population as developing regions, but this pattern will still have an impact in England's capital. With London already a global megacity and a magnet for culture with a strong economy, the population projections surmised in this study are well within the realm of possibility, and perhaps probability. 
Further perspective is warranted regarding the continued growth of population in projected inundated areas. Clearly, if the SLR scenarios presented in this study come to pass, there would not be continued development in the affected areas. However, this study stands to predict how much available city area would be lost to inundation which includes significant real estate values. In addition, if a barrier capable of withstanding such SLR was constructed and failed such as the levees protecting New Orleans from Hurricane Katrina, the scenarios presented in this study provide an approximation of consequences.

There are potential improvements to the methodological and data decisions made in this study. Accurately predicting how inundation may behave once encountering the Thames Barrier could have been exercised through a utilization of a flow direction raster to determine the relationship of neighboring pixels on the eastern edge of the barrier (Poulter and Halpin 2007). As of now, this study equipped with a simple bathtub model assumed inundation would stay stable and rise evenly in all areas. Lack of time and experience with more complicated Flow Direction tools led to the decision of the simplistic bathtub model albeit its limitations when compared to realistic hydrological tendencies. However, this improvement could be applied in future studies. The risk assessment in this study is taken as a simple, binary measure of inundated versus safe populations. A more realistic model would incorporate probability percentages into the likelihood of simulated scenarios and the value of potential events as part of a more complex risk assessment such as Cartwright (2008). Also, a flow diagram providing visual representation of executed methods was considered but exceeded the domain of this study. 
Data acquisition pursued the use of EDs as the geographic boundary of choice for all empirical data to enhance the scale of precision in assuming population dispersion. However, EDs were only available for 1971-1991 while LSOAs were the smallest geography available for 2001-2011. LSOAs from 2011 were designated as the target zones for areal interpolation as they were the most recent and populated of the empirical census data, logically making the base for future projections. Also, a higher resolution DEM could have improved precision of SLR simulations due to enhanced topographic accuracy if better sources were readily available. However, a higher resolution DEM would have required significantly more computing power and may not have been feasible given the resources available to conduct this study.

The SLR in this study was simulated assuming progressive, relatively slow developing encroachment of coastal inundation. In reality, the Thames Barrier also faces inundation from high tides, storm surges, groundwater floods, etc., not just SLR. Vertical land movement is another factor that could complicate Greater London's vulnerability to inundation hazards but was not pursued under the scope of this study. If the Hansen et al. (2016) projections develop as anticipated, the effects and reaches of identified acute hazards will be far more pronounced as they synergize with steady SLR that fills the local basin. Assessing the impact of these acute hazards would likely require another study specifically dedicated to each.

This study assumed the Thames Barrier did not fail under the conservative $(1 \mathrm{~m})$ and moderate $(5 \mathrm{~m})$ scenarios as at this height, the Barrier should maintain protection. In realistic scenarios where the barrier was stressed at such capacities for an extended period, this may not have been the case. Lewin and Lavery (2008) touch on this 
regarding the barrier's reliability, ageing, and wear. The Thames Barrier is now 35 years old retaining a large number of components from original installation. Lewin and Lavery (2002, 201) continue with,

"There are over 300 limit switches, several hundred oil hydraulic valves, check valves, directional control valves, off loader and relief valves. Bearings, crossheads and operating cylinders, are duplicated at each pier. In some cases, components are no longer available or were purpose made for the Barrier. To anticipate failures requires estimating the residual life of components and forward planning for refurbishment and replacement of parts, and in the longer term, whole systems."

This study obviously did not seek to incorporate such uncertainty and academic research may not be the best venue for testing these outcomes. However, realistic planning and means of action should factor ageing and wear of the Thames Barrier and other flood defenses into the overall decision-making process. This is central when considering the estimation of 30 years to build a new barrier (Lewin and Lavery 2002). The total project time until completion was 29 years for the original Thames Barrier (Horner 1987). It is logical to expect a similar timeframe given the complexity of regulatory constraints for modern construction, however, perhaps modern technologies could expedite the process.

Another pivotal factor is that with SLR of this magnitude, the Thames Barrier would likely need to keep all gates closed indefinitely. This situation would make local river traffic impossible as gate openings would create a surge of water west of the barrier and its design may not support opening under such conditions. Usually, the barrier remains closed to through traffic when faced with a strong surge or exceptional high tide until the water recedes. This dilemma remains the same even under the protection of a new barrier unless it can be engineered to safely open and close under such conditions or came equipped with a sophisticated lock system. 
Adding more complexity for London and the collective UK, is the recent Brexit decision to withdraw from the European Union. Terms of the deal are still being negotiated and without even an opening offer on the table as of yet (James 2017), Brexit adds even more uncertainty to London's $21^{\text {st }}$ century social prospects. Much of the early terms of the deal focused on limiting immigration as Brexit supporters favored tightening the loose policies that the UK has exercised in recent times (Wadsworth et al. 2016). This is a factor that could yield great significance towards London's population changes in the coming decades. Immigration reform is but a single factor and with all the uncertainty surrounding Brexit, this study did not attempt to incorporate any of the variables in its agenda. However, with such a heavy political shift in the balance, closely monitoring and adjusting variables within population projection formulas would be wise for future studies on the UK.

Originally, cost of relocation was considered to add depth to the results of this study. However, with all the uncertainty already in play regarding climate change and population growth, efforts to quantify and project this variable were abandoned. With much of hazards based research built upon reflecting potential damages (Cutter, Boruff, and Shirley 2003), valuation of relocation costs and physical damages remain promising challenges for future studies.

These are but a few discussion points that arose throughout the development of this study. As our understanding of climate change evolves, policy and projections become reality, methodological tools advance, and new data become available, scientific research must keep pace to pioneer London's adaptive resilience throughout the $21^{\text {st }}$ century and beyond. 


\section{SUMMARY AND CONCLUSIONS}

SLR is an approaching threat for coastal regions under scenarios of $21^{\text {st }}$ century climate change. Global authorities are insufficiently combatting climate change via reduced consumption of fossil fuels and official policies and guidelines are underestimating potential SLR. In result, most coastal areas are not adequately equipped to handle projected SLR inundation, including Greater London despite its impressive flood defense infrastructure. Hansen et al. (2016) warnings were applied to future scenarios of London and with over one-third of the city's population inundated by 2101 , results support the proposed hypothesis that Greater London is not prepared for projected SLR in the $21^{\text {st }}$ century.

The importance of this study lies in its boldness to challenge embedded assumptions regarding the higher end of possible SLR scenarios. As with all studies that include a high level of uncertainty, more research along with further monitoring of climate change variables remains imperative. However, combatting climate change requires a long-term approach demanding solutions that begin today. Despite current efforts on this front, more initiative is necessary to understand and resist the effects of significant SLR. A global call to action with a sense of urgency is necessary as hazardous events have shown that investment is more effective with proactive strategies rather than reactive responses. On a global scale, decidedly more needs to be done to abate the source of human generated climate change by limiting the expulsion of $\mathrm{CO}_{2}$ into 
the atmosphere and oceans. Without an about face from societal behaviors in the industrialized era, London and all coastal cities have their work cut out for them.

The results of this study may be a worst-case scenario but perhaps not. None of the concerned parties in Greater London are considering scenarios quite like Hansen et al. (2016) and their actions follow suit. Nevertheless, the fact remains that if it does indeed take 30 years to implement a new barrier, the time to act is now to get ahead of an unfortunate future. If Greater London, and other densely populated coastal areas, delay in appropriating mitigation measures against SLR, all indications are that significant social, economic, and environmental disruption is likely within the coming century. 


\section{REFERENCES}

Archer, D. 2005. Fate of fossil fuel CO2 in geologic time. Journal of Geophysical Research: Oceans 110 (C9): 1-6.

Archer, D., and V. Brovkin. 2008. The millennial atmospheric lifetime of anthropogenic CO2. Climatic Change 90 (3): 283-297.

Atkins Limited. 2014. London 2100 Future Proofing London for the next century. 1-21.

Bangladesh Bureau of Statistics (BBS). 2015. Population Density And Vulnerability: A Challenge For Sustainable Development Of Bangladesh. Dhaka: Ministry of Planning 7: 1-129.

Black, R., W. Adger, N. W. Arnell, S. Dercon, A. Geddes, and D. Thomas. 2011. The effect of environmental change on human migration. Global Environmental Change 21: S3-S11.

Bowen, A. 1972. The Tidal Regime of the River Thames; Long-Term Trends and their Possible Causes. Philosophical Transactions of the Royal Society of London. Series A, Mathematical and Physical Sciences 272 (1221): 187-199.

Cartwright, A. 2008. Global Climate Change and Adaptation - A Sea-Level Rise Risk Assessment. Phase three: Final Report A Sea-Level Rise Risk Assessment for the City of Cape Town. Cape Town, SA: Stockholm Environment Institute. 1-65.

Cutter, S. L., B. J. Boruff, and W. L. Shirley. 2003. Social Vulnerability to Environmental Hazards. Social Science Quarterly 84 (2): 242-261.

Department of the Environment. 1981. 1981 Census: Digitized Boundary Data (England and Wales). UK Data Service Census Support. Available at http://casweb.ukdataservice.ac.uk (Last accessed 28 July 2017).

Ed-Line Consortium. 1991. 1991 Census: Digitized Boundary Data (England and Wales). UK Data Service Census Support. Available at http://casweb.ukdataservice.ac.uk (Last accessed 28 July 2017).

Environment Agency. 2012. Thames Estuary 2100 - Managing flood risk through London and the Thames estuary. London, UK: 1-230. 
Environment Agency. 2017a. Flood risk assessment: standing advice - GOV.UK. Available at https://www.gov.uk/guidance/flood-risk-assessment-standing-advice (last accessed 20 November 2017).

Environment Agency. 2017b. The Thames Barrier. Available at https://www.gov.uk/guidance/the-thames-barrier (last accessed 8 November 2017).

Fekete, H., L. Luna, S. Sterl, F. Hans, S. Gonzales, N. Höhne, L. Wong, Y. Deng, G. U. Rehman Mir, Y. Monschauer, T. Berg, K. Blok, J. Cantzler, U. Ural, P. Yanguas Parra, M. Schaeffer, B. Hare, and A. Ancygier. 2017. Improvement in warming outlook as India and China move ahead, but Paris Agreement gap still looms large. Climate Action Tracker : 1-18.

Gotway, C. A., and L. J. Young. 2002. Combining Incompatible Spatial Data. Journal of the American Statistical Association 97 (458):632-648.

Grant, K. M., E. J. Rohling, M. Bar-Matthews, A. Ayalon, M. Medina-Elizalde, C. B. Ramsey, C. Satow, and A. P. Roberts. 2012. Rapid coupling between ice volume and polar temperature over the past 150,000 years. Nature: 744-747.

Greater London Authority. 2015. Population Growth in London, 1939-2015. GLA Intelligence. https://files.datapress.com/london/dataset/population-change-19392015/historical population 1939-2015.pdf (last accessed 10 November 16ADAD).

Hallisey, E., E. Tai, A. Berens, G. Wilt, L. Peipins, B. Lewis, S. Graham, B. Flanagan, and N. Buchanan Lunsford. 2017. Transforming geographic scale: a comparison of combined population and areal weighting to other interpolation methods. International Journal of Health Geographics: 1-16.

Hansen, J. 2008. Climate threat to the planet: implications for energy policy and intergenerational justice, Bjerknes lecture, American Geophysical Union, San Francisco, 17 December. http://www.columbia.edu/ jeh1/2008/AGUBjerknes20081217.pdf (last accessed 22 September 2017),

Hansen, J., R. Ruedy, M. Sato, and K. Lo. 2010. Global Surface Temperature Change. Reviews of Geophysics 48 (4). 1-9.

Hansen, J., M. Sato, P. Hearty, R. Ruedy, M. Kelley, V. Masson-Delmotte, G. Russell, G. Tselioudis, J. Cao, E. Rignot, I. Velicogna, B. Tormey, B. Donovan, E. Kandiano, K. Von Schuckmann, P. Kharecha, A. N. Legrande, M. Bauer, and K.W. Lo. 2016. Ice melt, sea level rise and superstorms: evidence from paleoclimate data, climate modeling, and modern observations that $2{ }^{\circ} \mathrm{C}$ global warming could be dangerous. Atmos. Chem. Phys. 16 (6): 3761-3812. 
Hawkins, E., P. Ortega, E. Suckling, A. Schurer, G. Hegerl, P. Jones, M. Joshi, T. Osborn, V. Masson-Delmotte, J. Mignot, P. Thorne, and G. van Oldenborgh. 2017: Estimating changes in global temperature since the pre-industrial period. Bull. Amer. Meteor. Soc. September. 1841-1856.

Hawley, K., and H. Moellering. 2005. A comparative analysis of areal interpolation methods. Cartography and Geographic Information Science 32 (4): 411-423.

Hoffert, M. I., K. Caldeira, G. Benford, D. R. Criswell, C. Green, H. Herzog, A. K. Jain, H. S. Kheshgi, K. S. Lackner, J. S. Lewis, H. D. Lightfoot, W. Manheimer, J. C. Mankins, M. E. Mauel, L. J. Perkins, M. E. Schlesinger, T. Volk, and T. M. L. Wigley. 2002. Advanced Technology Paths to Global Climate Stability: Energy for a Greenhouse Planet. Science 298 (5595): 981-987.

Hoornweg, D., and K. Pope. 2014. Socioeconomic Pathways and Regional Distribution of the World's 101 Largest Cities. Global Cities Institute. 1-119.

Horner, R. 1987. The Thames Barrier. IEE Proceedings A - Physical Science, Measurement and Instrumentation, Management and Education - Reviews 134 (9): $752-760$.

Institute of Planning and Urban Development of the Ile-de-France Region. 2007. Large-scale urban development projects in Europe. Available at: https://www.iauidf.fr/en/know-how/scope-of-activities/edition/large-scale-urban-developmentprojects-in-europe.html (last accessed 31 October 2017).

IPCC. 2014a. Summary for policymakers. In: Climate Change 2014: Impacts, Adaptation, and Vulnerability. Part A: Global and Sectoral Aspects. Contribution of Working Group II to the Fifth Assessment Report of the Intergovernmental Panel on Climate Change [Field, C.B., V.R. Barros, D.J. Dokken, K.J. Mach, M.D. Mastrandrea, T.E. Bilir, M. Chatterjee, K.L. Ebi, Y.O. Estrada, R.C. Genova, B. Girma, E.S. Kissel, A.N. Levy, S. MacCracken, P.R. Mastrandrea, and L.L. White (eds.)]. Cambridge University Press, Cambridge, United Kingdom and New York, NY, USA. 1-32.

IPCC. 2014b. Summary for Policymakers. In: Climate Change 2014: Mitigation of Climate Change. Contribution of Working Group III to the Fifth Assessment Report of the Intergovernmental Panel on Climate Change [Edenhofer, O., R. Pichs-Madruga, Y. Sokona, E. Farahani, S. Kadner, K. Seyboth, A. Adler, I. Baum, S. Brunner, P. Eickemeier, B. Kriemann, J. Savolainen, S. Schlömer, C. von Stechow, T. Zwickel and J.C. Minx (eds.)]. Cambridge University Press, Cambridge, United Kingdom and New York, NY, USA. 1-30.

James, W. 2017. Britain to submit 'Brexit bill' proposal before December EU meeting. Reuters. Available at https://www.reuters.com/article/uk-britain-eu- 
hammond/britain-to-submit-brexit-bill-proposal-before-december-eu-meetingidUSKBN1DJ0AJ (last accessed 22 November 2017).

Jenkins, D. G., and L. A. McCauley. 2006. Proceedings of the 2006 ACM symposium on Applied computing. In GIS, SINKS, FILL, and disappearing wetlands: unintended consequences in algorithm development and use, 277-282. New York, NY: ACM https://dl.acm.org/citation.cfm?id=1141342 (last accessed 9 October 2017).

Jones, M. 2007. Rising groundwater in central London. Water and Sewerage (4): 35-36.

Kennedy, C., J. Cuddihy, and J. Engel-Yan. 2007. The Changing Metabolism of Cities. Journal of Industrial Ecology 11 (2): 43-59.

Krivoruchko, K., A. Gribov, and E. Krause. 2011. Multivariate Areal Interpolation for Continuous and Count Data. Procedia Environmental Sciences (3): 14-19.

Lacis, A. A., G. A. Schmidt, D. Rind, and R. A. Ruedy. 2010. Atmospheric CO2: Principal Control Knob Governing Earth's Temperature. Science 330 (6002): 356359.

Lam, N. S.-N. 1983. Spatial Interpolation Methods: A Review. The American Cartographer 10 (2): 129-150.

Lavery, S., and B. Donovan. 2005. Flood risk management in the Thames Estuary looking ahead 100 years. Philosophical Transactions of the Royal Society A: Mathematical, Physical and Engineering Sciences 363 (1831): 1455-1474.

Lenati, A. 2016. London population forecast to hit $13 \mathrm{~m}$ by 2050. Evening Standard. Available at https://www.standard.co.uk/news/london/london-population-forecastto-hit-13m-by-2050-a3168091.html (last accessed 20 November 2017).

Lewin, J., and S. Lavery. 2002. Maintaining Thames tidal defences in a century of climate change. Reservoirs in a Changing World: Proceedings of the 12th Conference of the British Dam Society 193-208.

Macdonald, D., A. Dixon, A. Newell, and A. Hallaways. 2011. Groundwater flooding within an urbanised flood plain. Journal of Flood Risk Management 5 (1): 68-80.

Mahapatra, S. K., and K. C. Ratha. 2016. Paris Climate Accord: Miles to Go. Journal of International Development 29 (1):147-154.

Mauritsen, T. and R. Pincus. 2017. Committed warming inferred from observations. Nature Climate Change (7): 652-655. 
McDougall, R. 2010. The UK's population problem. Population Matters. https://populationmatters.org/wp-content/uploads/population_problem_uk.pdf (Last accessed 16 October 2016).

McGregor, D. 2012. 2011 Census - Population and Household Estimates for England and Wales, March 2011. London, UK.

Met Office. 2011. Together Make a difference with a coordinated response to emergency management. Available at http://www.metoffice.gov.uk/media/pdf/a/o/11_0194_PWS_Together_Brochure1. pdf (last accessed 23 November 2016).

Milman, O. 2016. Climate guru James Hansen warns of much worse than expected sea level rise. The Guardian. Available at https://www.theguardian.com/science/2016/mar/22/sea-level-rise-james-hansenclimate-change-scientist (last accessed 24 August 2017).

Nickson, A. 2011. Cities and Climate Change: Adaptation in London, UK. Global Report on Human Settlements. 1-15.

NOAA. 2013. Carbon Dioxide at Mauna Loa reaches new milestone: Tops $400 \mathrm{ppm}$. ESRL News. Available at https://www.esrl.noaa.gov/news/2013/CO2400.html (last accessed 19 November 2017).

NOAA. 2017. Trends in Atmospheric Carbon Dioxide. Earth System Research Laboratory Global Monitoring Division. Available at https://www.esrl.noaa.gov/gmd/ccgg/trends/monthly.html (last accessed 29 November 2017).

Office for National Statistics. 2001. 2001 Census: Digitized Boundary Data (England and Wales). UK Data Service Census Support. Available at http://geoportal.statistics.gov.uk/ (Last accessed 28 April 2017).

Office for National Statistics. 2011a. 2001 Census aggregate data (Edition: May 2011). UK Data Service. Available at https://www.nomisweb.co.uk/ (Last accessed 28 April 2017).

Office for National Statistics. 2011b. 2011 Census: Digitized Boundary Data (England and Wales). UK Data Service Census Support. Available at http://geoportal.statistics.gov.uk/ (Last accessed 28 April 2017).

Office for National Statistics. 2016. 2011 Census aggregate data. UK Data Service (Edition: June 2016). Available at https://www.nomisweb.co.uk/ (Last accessed 28 April 2017). 
Office for National Statistics. 2017. Overview of the UK population: July 2017.

Available at

https://www.ons.gov.uk/peoplepopulationandcommunity/populationandmigration/ populationestimates/articles/overviewoftheukpopulation/july2017\#the-ukpopulation-is-at-its-largest-ever (last accessed 25 November 2017).

Office For National Statistics. n.d. Census Geography - An Overview of the Various Geographies Used in the Production of Statistics Collected Via the UK Census. Available at https://www.ons.gov.uk/methodology/geography/ukgeographies/censusgeography \#super-output-area-soa (Last Accessed 10/30/17).

Office of Population Censuses and Surveys. 1997. 1991 Census aggregate data. UK Data Service. Available at http://casweb.ukdataservice.ac.uk/ (Last accessed 28 July 2017).

Office of Population Censuses and Surveys. 2000. 1981 Census aggregate data (Edition: 2000). UK Data Service. Available at http://casweb.ukdataservice.ac.uk/ (Last accessed 28 July 2017).

Ordinance Survey Limited. 2017. OS Terrain 50. Available at https://www.ordnancesurvey.co.uk/ (Last accessed 29 January 2017)

Parker, D. J. 1999. Disaster response in London: A case of learning constrained by history and experience. In Crucibles of Hazard: Mega-cities and Disasters in Transition, 186-247. United Nations University Press.

Piguet, E., and F. Laczko. 2014. People on the move in a changing climate: the regional impact of environmental change on migration - Global Migration Issues. Springer.

Pollard, D., R. M. DeConto, and R. B. Alley. 2015. Potential Antarctic Ice Sheet retreat driven by hydrofracturing and ice cliff failure. Earth and Planetary Science Letters 412: 112-121.

Poulter, B., and P. N. Halpin. 2007. Raster modelling of coastal flooding from sea-level rise. International Journal of Geographical Information Science 22 (2): 1-16.

Ranger, N., T. Reeder, and J. Lowe. 2013. Addressing 'deep' uncertainty over long-term climate in major infrastructure projects: four innovations of the Thames Estuary 2100 Project. EURO Journal on Decision Processes 1 (3-4): 233-262.

Registrar General for England and Wales. 1971a. 1971 Census aggregate data. UK Data Service. Available at http://casweb.ukdataservice.ac.uk/ (Last accessed 28 July 2017). 
Registrar General for England and Wales. 1971b. 1971 Digitized Boundary Data (England and Wales). UK Data Service. Available at http://casweb.ukdataservice.ac.uk/ (Last accessed 28 July 2017).

Reibel, M., and A. Agrawal. 2007. Areal Interpolation of Population Counts Using Preclassified Land Cover Data. Population Research and Policy Review 26 (5-6): 619-633.

Rogelj, J., M. D. Elzen, N. Höhne, T. Fransen, H. Fekete, H. Winkler, R. Schaeffer, F. Sha, K. Riahi, and M. Meinshausen. 2016. Paris Agreement climate proposals need a boost to keep warming well below $2{ }^{\circ} \mathrm{C}$. Nature 534 (7609): 631-639.

Rummukainen, M. 2015. Our commitment to climate change is dependent on past, present and future emissions and decisions. Climate Research 64 (1): 7-14.

Sallenger, A. H., K. S. Doran, and P. A. Howd. 2012. Hotspot of accelerated sea-level rise on the Atlantic coast of North America. Nature Climate Change 2: 884-888.

Schoon, N. 1998. Rural crisis: Urban sprawl - Inch by inch, England's green and pleasant land is slowly disappearing. The Independent.

https://www.independent.co.uk/news/rural-crisis-urban-sprawl-inch-by-inchenglands-green-and-pleasant-land-is-slowly-disappearing-1141047.html (last accessed 18 October 2017).

Tacoli, C. 2009. Crisis or adaptation? Migration and climate change in a context of high mobility. Environment and Urbanization 21 (2): 513-525.

Tarboton, D. G., R. L. Bras, and I. Rodriguez-Iturbe. 1991. On the extraction of channel networks from digital elevation data. Hydrological Processes 5 (1): 81-100.

The Engineer. 2003. Closing the Floodgates. https://www.theengineer.co.uk/issues/12september-2003/closing-the-floodgates/ (Last accessed 11 November 2016).

Travers, T. 2004. The Politics of London: Governing an Ungovernable City. Houndmills, Basingstoke, Hampshire: Palgrave Macmillan.

United Nations. 2016. Paris Agreement. Chapter XXVII Environment. Available at https://treaties.un.org/pages/ViewDetails.aspx?src=TREATY\&mtdsg_no=XXVII7-d\&chapter=27\&clang=_en (last accessed 19 September 2017).

Wadsworth, J., S. Dhiringa, G. Ottaviano, and J. V. Reenan. 2016. Brexit and the Impact of Immigration on the UK. BREXIT 2016 Policy analysis from the Centre for Economic Performance. 34-53.

Watson, Jo. 2009. Access to Nature Regional Targeting Plan - LONDON. Natural England. 1-7. 
Watts, M. 2017. Cities spearhead climate action. Nature Climate Change 7 (8): 537538.

Wolff, S. 2015. Migration and Refugees in the Mediterranean: Rethinking Geopolitical Constraints, Western-centric Policies and Mobility's Precariousness.

Mediterranean Politics 20 (3): 439-444.

Yunus, A., R. Avtar, S. Kraines, M. Yamamuro, F. Lindberg, and C. Grimmond. 2016. Uncertainties in Tidally Adjusted Estimates of Sea Level Rise Flooding (Bathtub Model) for the Greater London. Remote Sensing 8 (5): 366. 
APPENDIX A

IPCC Terms Central for Understanding

(adapted from IPCC 2014a; IPCC 2014b) 
Exposure - The presence of people, livelihoods, environmental functions, services, resources, infrastructure, or economic, social, or cultural assets in places and settings that could be adversely affected.

Impacts - Effects of extreme weather, climate events, and climate change on natural and human systems. Impacts are directly linked to exposure and generally refer to the same variables, due to the interaction of climate changes or hazardous climate events occurring within a specific time period and the vulnerability of an exposed society or system. Of these, the IPCC stated impacts from recent climate-related extremes, such as floods, reveal significant vulnerability and exposure of many human systems to current climate variability. For countries at all levels of development, these impacts are consistent with a significant lack of preparedness towards current climate variability.

Adaptation - The process of adjustment to actual or expected climate and its effects. In human systems, adaptation attempts to moderate or avoid harm and exploit beneficial opportunities. Adaptation and mitigation choices in the near term will affect the risks of climate change throughout the 21 st century and responding to climate-related risks involves decision making in a changing world, with continuing uncertainty about the severity and timing of climate-change impacts. Urban adaptation benefits from effective multi-level urban risk governance, alignment of policies and incentives, strengthened local government and community adaptation capacity, synergies with the private sector, and appropriate financing and institutional development. 
Vulnerability - The propensity or predisposition to be adversely affected.

Vulnerability can encompass a variety of concepts and elements, including sensitivity or susceptibility to harm and lack of capacity to cope and adapt. These shape differential risks from climate change and can be attributed to uneven development processes such as marginalized people.

Risk - The potential for consequences where something of value is at stake with an uncertainty of outcome.

Resilience - The capacity of social, economic, and environmental systems to cope with a hazardous event, trend, or disturbance, responding or reorganizing in ways that maintain their essential function, identity, and structure, while also maintaining the capacity for adaptation, learning, and transformation. 


\section{CURRICULUM VITA}

Nathan Wright

903 Ahland Rd. Louisville, KY 40207

502-930-3764

nkwrig01@gmail.com

\section{EDUCATION}

University of Louisville, Louisville, KY (2014-2017)

M.S. in Geography \& Geosciences (In Progress)

M.S. Thesis (Fall 2017): Greater London In The $21^{\text {st }}$ Century: Assessing Coastal

Flooding Mitigation Preparedness and Regional Population Risk in the Face of Projected Sea Level Rise

3.9 GPA

University of Louisville, Louisville, KY (2005-2010)

B.S.B.A in Marketing with a focus in Sales

3.2 GPA

\section{RESEARCH INTERESTS}

Climate Change

Sea-Level Rise

Critical Infrastructure

Coastal Management

Population Growth

Urbanization

Evolutionary Biology

Ancestral Health

\section{TEACHING EXPERIENCE}

Teaching Assistant \& Lecturer, University of Louisville, Louisville, KY (2016Present)

Geography \& Geosciences Department

GEOS 200 - The Global Environment

Taught class, organized assignments, moderated weekly discussion forums, processed weekly grading, substituted for other course sections when primary instructors were absent 


\section{AWARDS AND HONORS}

Outstanding Graduate in Geography (2017)Study Abroad - Bregenz, Austria (Summer 2009)

Dean's List - 4 quarters (2007-2010)

\section{ACADEMIC SERVICE}

Departmental Graduate Network for Arts \& Sciences (GNAS) representative - (Fall 2016-Spring 2017)

Delphi U Certification (2016)

Kennesaw State University's National Collegiate Sales Competition (2010) - Student Coach

Ball State University \& Great Northwoods National Collegiate Sales Competitions Participant (2008-2009)

\section{MEMBERSHIPS}

Geography Club (Fall 2014-Fall 2017)

Student Marketing Association (Fall 2009-Spring 2010)

Student Sales Network (Fall 2009-Spring 2010)

\section{LEARNING MANAGEMENT SYSTEMS}

Blackboard

\section{REFERENCES}

Available upon request 